\title{
Osmanlı Vakıflarının Tüzel Kişiliği Var mıydı?
}

\author{
YAKUP AKKUŞ* \\ yakupak@istanbul.edu.tr \\ ORCID ID: 0000-0001-6506-5030
}

Öz: Tüzel kişilik kavramı ve kurumu özü itibariyle Batı Avrupa Hukuku’na aittir. İslam ve Osmanlı vakıflarının tüzel kişiliği ise literatürde yeterince irdelenmiş değildir. Bu çalışmada, vakıfların vakfiyelerine göre yönetilmesi, mütevellileri yoluyla kendi gelir-giderlerini idare etmesi, davalı ve davacı olabilmesi, malvarliğına sahip olması, borçlu ve alacaklı olabilmesi gibi kriterler dikkate alınarak; genel anlamda Osmanl vakıflarının, İslam Hukuku'na göre, tüzel kişiliğe sahip olduğu kabul edilmiştir. Ancak Osmanl vakıflarının tüzel kişilikleri, devletin sıkı denetimi veya doğrudan yönetime müdahalesi sebebiyle, filiyatta Avrupa'daki muadillerine nazaran zayıf kalmaktadır. Bunların yanında, vakıfların tüzel kişilikleri tartışılırken vakıf türlerinin göz önüne alınması gerekir. Bilhassa bu konuya yoğunlaşan çalışmada, sultan vakıfları ile büyük çaplı vakıfların de facto tüzel kişiliklerinin, küçük çaplı vakıflar ile aile vakıflarının tüzel kişiliklerine kıyasla daha zayıf olduğu sonucuna varılmıştır. Mülhak vakıfların tüzel kişiliğinin olduğu; mütevellileri olmayan ve doğrudan Evkaf Nezareti tarafından yönetilen mazbut vakıfların ise tüzel kişiliklerinin olmadığı öne sürülmüştür. Ayrıca çalışmada, vakıfların tüzel kişiliği ile iktisadi gelişme arasındaki teorik ilişkiye değinilmiştir.

Anahtar kelimeler: Vakıf hukuku, Tüzel kişilik, Özerklik, Osmanlı vakıfları, Avrupa vakıfları.

\section{Giriş̧}

Günümüz medeni hukukuna göre tüzel kişiler, birden fazla gerçek kişinin "belirli" ve "sürekli" bir amaç doğrultusunda oluşturdukları, bağımsız bir varlık şeklinde örgütlenmiş olan kişi ve mal topluluklarıdır. Tüzel kişinin, kendisini oluşturan gerçek kişilerin iradelerinden bağımsız ayrı bir iradesi vardır. Bu iradenin varlığı sayesinde tüzel kişiler, karar organları aracılığıyla hak ve borç altına girebilirler. Tüzel kişilerin kişi ve mal toplulukları olarak hak öznesi (kişi) olabilmeleri için gerekli organlara sahip olmaları/örgütlenmeleri gerekir. Ancak bu yolla bağımsız bir hak öznesi sıfatını alabilir ve böylece fiil ehliyetine de sahip olurlar. Organın eylemleri ve hukuki işlemleri bağlayıcıdır; yani parçası olduğu tüzel kişi tarafından yapılmış kabul edilecektir.

* Dr. Öğr. Üyesi, İstanbul Üniversitesi, İktisat Bölümü, İktisat Tarihi Anabilim Dalı. 
Tüzel kişiler, “özel hukuk tüzel kişileri” ve "kamu hukuku tüzel kişileri” biçiminde ikiye ayrılırlar. Günümüz hukuk düzenine göre, özel hukuk tüzel kişisi olan vakıflar, bir kişinin belli bir malını yine belli bir amaca tahsis etmesiyle kurulan mal topluluklarıdır. Vakıflarda asli unsur mal varlığı olduğundan; vakfın yöneticileri, çalışanları ve vakfın hizmetlerinden yararlananlar ise bu tüzel kişinin bir unsuru değildir. ${ }^{1}$

Osmanlı vakıflarının başlıca organı da mütevelli idi. Mütevelli, vakfiyede bahsi geçen işleri kurucunun şartları doğrultusunda yerine getirirdi. Osmanlı vakıfları belirli ve sürekli amaçlar için kurulur, kurucu tarafindan mütevelli tayin edilmemişse tayini kadılar yapardı. Bazı durumlarda mütevelli yerine, kadı tarafından, "mütevelli kaymakamı" da tayin edilebilirdi. Literatürdeki genel kanaate göre, mütevelli "vakıf hükmî şahsının” yani tüzel kişiliğinin karar ve icra organı, aynı zamanda temsilcisiydi. $^{2}$

$\mathrm{Bu}$ çalışma, literatürde yeterince irdelenmeyen, Osmanlı vakıflarının tüzel kişilik konusunu tartışma amacındadır. Bu spesifik konunun kapsamlı bir şekilde ele alınmaması bir yana, İslam hukukunda sadece vakıfları ele alan eserlerin sayısı dahi sınırlıdır. Nitekim bu yaklaşım Osmanlı hukuk çalışmalarına da yansımıștır. Özcan, Osmanlı vakıf hukuku alanındaki çalışma sayısının azlığına, yetersizliğine ve bu alandaki en ciddi araştırmaların Batılı akademik çevreler tarafından yapıldığına dikkat çekmiştir. $^{3}$

Makalede öncelikle Avrupa ve İslam hukuk geleneklerinde tüzel kişiliğin yeri karşılaştırmalı biçimde gösterilmeye çalışılacaktır. Ardından ikinci kısımda Osmanlı hukuk rejiminde vakıfların idare tarzı ile tüzel kişiliği üzerine literatürdeki görüşler aktarılacaktır. Osmanlı vakıflarının tüzel kişiliği konusu tartışılırken hangi vakıfların bahis konusu edildiği önemlidir. Genel anlamda literatürde ihmal edilen bu konu üçüncü kısımda ayrıca ele alınacaktır. Dördüncü kısımda şer’iye sicillerinden yola çıkarak Osmanlı vakıflarının tüzel kişiliğe sahip olup olmadığına dair de facto kanıtlar aranacaktır. Son kısımda ise vakıfların tüzel kişiliğinin iktisadi ve toplumsal açıdan önemine ve bu alanlara yansımasına kısaca değinilecektir.

\section{Avrupa ve İslam Hukuk Geleneğinde Tüzel Kişilik Konusu}

Batı Avrupa'ya ait bir kavram ve kurum olan korporasyon (yasal ya da tüzel kişilik) Roma İmparatorluğu karşısında bağımsızlığını korumak isteyen- Katolik Kilisesi tarafından teoriye ve pratik alana kazandırılmıştır. Roma Katolik Kilisesi, korporasyon biçiminde organize olurken, çağdaşı olan Doğu Ortodoks Hristiyanlığın ve İslam medeniyetinin kavram dünyasında bu tip bir kurum oluşmamıştır. Avrupa'da korporasyon tipi örgütlenmenin ticari alana girişi ise asırlar sonra 16. ve 17. yüzyıllarda

1 Kemal Gözler, İdare Hukuku, C. 1, 1. baskı, Bursa: Ekin Kitabevi, 2003, s.132-133; Âlim Taşkın, “Tüzel Kişilerin Kişilik Haklarının Korunması”, Ankara Üniversitesi Hukuk Fakültesi Dergisi, 42/1 (1992), s.206, 217.

2 Sıddık Sami Onar, İdare Hukukunun Umumi Esasları, C. 1, İkinci Baskı, İstanbul: İsmail Akgün Matbaası, 1960, s.546-547; Ahmet İşeri, "Vakıflar (Medeni Kanun'dan Önceki ve Sonraki Vakıf Nev'ileri ve Hukukî Mahiyetleri)", Ankara Üniversitesi Hukuk Fakültesi Dergisi, 21/1 (1964), s.234.

3 Tahsin Özcan, “Osmanlı Vakıf Hukuku Çalışmaları”, Türkiye Araştırmaları Literatür Dergisi, $3 / 5$ (2005), s.515$516,534$. 
Doğu Hindistan şirketlerinin ortaya çıkışıyla gerçekleşmiştir. ${ }^{4}$

19. yüzyıla gelindiğinde, batı toplumlarında merkezi devletler güçlenmiş ve "kiliseye ve büyük servetlere sahip bulunan kilise vakıflarına karşı” mücadele başlatmıştı. Bu sebeple, 20. yüzyılda batıda vakıf kurma sayısında azalma yaşandı. Vakıflara karş1 takınılan bu olumsuz tavır, bu ülkelerin medeni kanunlarının kodifikasyonuna da yansımıştı. Örneğin Fransız Medeni Kanunu’nda (1804) vakıf kurma işlemi yer almamıştı. Vakıf kurma, sadece bağışlama veya vesayet yoluyla yapılabiliyordu. Vakıfların tüzel kişilik kazanabilmesi de idari makamdan alınacak izne bağlanmıştı. Dahası vakıfların hak ve fiil ehliyetleri çok sınırlı tutulmuştu. Avusturya Özel Hukuku'nda da vakıf kurma konusu düzenlenmemişti. Vakfın kurulması ve tüzel kişilik kazanması yine idarenin iznine bağlıydı. Alman Medeni Kanunu'nda ise vakıf maddesi yer almış ancak burada da kuruluş ve tüzel kişilik konusu merkezi idarenin iznine bırakılmıştı. İsviçre Medeni Kanunu'nda dini vakıflarla aile vakıflarının kurulması ve tüzel kişilik kazanması için izin ve tescil şartı aranmamıştı. Bunlar dışındaki vakıflar içinse yine izin şartı aranmamış ancak ticaret siciline kaydedilmeleri (tescillenmeleri) şartı getirilmişti. ${ }^{5}$

İngiliz vakıfları ise Avrupa kıtasından farklı bir yol izledi. Bu vakıflar Avrupa’nın diğer vakıflarının aksine "ebedilik” özelliğine sahipti ve tüzel kişiliği vardı. Oxford'daki ilk üç kolej Üniversite Koleji (1249), Balliol Koleji (1266) ve Merton Kolejídir (1264). Bunlar arasında Merton, tüzel kişiliğe sahip vakıf formunda kurulmuş ilk kolejdi. Aslında Avrupa'da ilk kolej 1180'de Paris'te faaliyete geçmişti. Ancak bu kolej vakıf niteliğini haiz değildi; fakir öğrencilerin kalmaları amacıyla kurulmuştu. Makdisi’ye göre, Paris'teki kolejin kurucusu John of London, Kudüs'teki hac ziyareti sirasında Müslüman toplumunda gördügü medreselerden etkilenerek bu koleji kurmuş olmalıyd $1 .{ }^{6}$ Çizakça benzer bir yorumu Merton Koleji için yapmıştır. Ona göre tüzel kişiliğe sahip olan bu kolej, İslami vakıf ile Batı korporasyonun ilk gerçek senteziydi. Vakfın kurucusu olan Walter de Merton Haçlı Seferleri’ne katılmış ve Ortadoğu'dayken vakıf hakkında bilgi edinmişti. ${ }^{7}$

Makdisi, İslam vakıflarının tüzel kişiliğe sahip olmadığı kanaatindedir. İslam dünyasındaki medreselerin İngiliz üniversiteleri karşısındaki başarısızlığının sebeplerinden biri olarak da medreselerin tüzel kişiliğinin yokluğunu gösterir. Bu bağlamda tüzel kişiliği olan vakıf kuruluşlarının daha esnek ve değişime açık olduğu, vakfiyelerine bağımlı olan ve yasal/tüzel kişilikleri olmayan (İslami) vakıfların ise bu niteliklerden yoksun olduğu görüşündedir. ${ }^{8}$ Buna ek olarak, Makdisi’ye göre, vakfın iki

4 Murat Çizakça, “Gerçekten de Suçlu Şeriat mıydı?”, erişim 10 Haziran 2018, https://www.academia.edu/4588011/ Gercekten_de_Suclu_Seriat_miydi, s.2-5; Timur Kuran, “Orta Doğu’daki Ekonomik Azgelişmişliğin Kurumsal Kökenleri”, Kayseri Ticaret Odası Dergisi, (Ekim 2010), s.57.

5 Erol Cansel, "Vakıf, Kuruluşu, İşleyişi ve Amacı", Vakıflar Dergisi, 20 (1988), s.321-322.

6 George Makdisi, The Rise of Colleges, Institutions of Learning in Islam and the West, Edinburgh: Edinburgh University Press, 1981, s.225-229.

7 Murat Çizakça, "Waqf and Reforming the Higher Education" (Paper to be submited at the higher education Forum -Waqf Revival, Malaysia, Kuala Lumpur, 22.02.2018), erişim 5 Haziran 2018, https://www.academia. edu/35870638/Waqf_and_Reforming_the_Higher_Education, s.2.

8 Makdisi, The Rise of Colleges, s.235-237. Çizakça da aynı görüştedir. Bkz. Çizakça, "Waqf and Reforming”, s.4-5. 
özelliği dokunulmazlık ve ebediliktir. Bu bağlamda, İslam vakıfları ile tüzel kişiliğe sahip Batı vakıfları arasındaki en önemli fark tüzel kişiliğin vakfa güvenlik, dayanıklılık ve devamlılık imkânı sunmasıdır. Çünkü Avrupa'da ve Amerikan kolonilerinde ülkenin genel kanunuyla (anayasa) vakfın bu yasal/tüzel kişiliği tanınmış ve koruma altına alınmıştır. ${ }^{9}$ Oysa çağdaşları olan Osmanlı'da Kanun-i Esasi’ye (1876) kadar genel bir kanundan ya da anayasadan bahsetmek mümkün olmadığından, Osmanlı vakıfları için bu tip bir güvence ve korumadan bahsedilemez.

Timur Kuran’a göre de İslam medeniyetinin hâkim olduğu Ortadoğu'da hukuk sistemi tüzel kişilik kavramına yabancıdır. ${ }^{10}$ Gerçekten İslam hukukçuları tüzel kişilik kavramını diğer kavram ve konulardan ayrı biçimde incelememişlerdir. Ancak Köse’ye göre modern hukuktaki tüzel kişilik anlayışına ve işleyişine benzer örgütlenmeler İslam Hukuku'na yabancı ya da aykırı değildir. ${ }^{11}$ Zahraa ise daha açık bir ifadeyle, İslam hukukçularının -doğrudan telaffuz etmeseler de- tüzel kişilik (juristic personality) kavramını tanıdıklarını kabul eder. Zahraa, İslam hukukçularının tüzel kişiliğe eşdeğer bir doktrin olarak "dhimma” kavramını geliştirdiklerini öne sürmüştür. Buna göre, dhimma doktrini "yasal kapasite” (legal capacity) doktrini ile birlikte geliştirilmiştir ve her ikisi de tüzel kişilik (legal/juristic personality) kavramına hizmet etmek ve unsurlarını açıklığa kavuşturmak için tanımlanmıştır. ${ }^{12}$ İslam Hukuku’nda vakıf idarecisi, vakıf adına borç alabilmek için kadıdan izin alabilir. Zahraa’ya göre, bu borcu yüklenen idareci değil; vakfın tüzel kişiliğidir. ${ }^{13}$ Hâtemî, İslam Hukuku’nda tüzel kişilik teriminin açıkça kullanılmamış ve teorinin Batıdaki ile aynı biçimde gelişmemiş olmasına rağmen, "vakıfların tüzel kişiliğinin kabul edildiğini söyleyebileceğimizi” yazmıştır. ${ }^{14}$ Köse benzer bir bakışla, İslam’da "manevi bir kişiliği” yani tüzel kişiliği olan müesseselerin (devlet, beytülmal, vakıf vs.) "gerçek kişiler" tarafından temsil edildiğini; vakıfların temsilcilerinin de mütevelliler olduğunu belirtmiştir. Buna göre, İslam'da vakıf hak sahibi olabilir ve yükümlülük altına girebilir. Zira vakıf ile gerçek kişiler arasında spesifik olarak kira sözleşmesi, mahsulatın satın alınması, istibdal (değiş-tokuş; satış) gibi hukuki işlemler ${ }^{15}$ gerçekleşir. Doğal olarak bu işlemleri vakıf adına bir gerçek kişinin yapması gerekir. Vakfın mütevellisi, nazırı ya da kayyumu olan bu kişiler, aynı zamanda mahkeme huzurunda davalı veya dava-

9 Makdisi, The Rise of Colleges, s.233.

10 Kuran, “Azgelişmişliğin Kurumsal Kökenleri”, s.58.

11 Murtaza Köse, "İslam Hukuku ve Modern Hukuka Göre Tüzel Kişilik”, EKEV Akademi Dergisi 1/2 (Mayıs 1998), s.226.

12 Mahdi Zahraa, "Legal Personality in Islamic Law", Arab Law Quarterly, 10/3 (1995), s.202-203, 206. Çizakça, dhimma için "Şirkete çok benzeyen dhimma, bir insanın içinde bulunduğu zamana ya da geleceğe ilişkin tüm hak ve sorumluluklarını içeren hayali bir havuz olarak varsayılır" açıklamasını yapmıştır. Bkz; Çizakça, "Suçlu Şeriat miydı?", s.11.

13 Zahraa, "Legal Personality", s.205.

14 Hüseyin Hâtemî, Medenî Hukuk Tüzel Kişileri: Giriş, Tarihi Gelişim, Eski Vakıflar, C. I, İstanbul: İstanbul Üniversitesi Hukuk Fakültesi Yayınları, 1979, s.352.

15 Kanlıca'da vakfa ait arsanın, kiracısına ait diğer bir mülk arsayla istibdali örneği için bkz; İstanbul Ahkâm Defterleri, İstanbul Vakıf Tarihi 1 (1742-1764), Proje ve Yayın Yön.: Ahmet Kal'a, haz., Ahmet Tabakoğlu, Ahmet Kal’a, Salih Aynural vd., İstanbul: İBB Kültür İşleri Daire Başkanlığı, İstanbul Araştırmaları Merkezi, 1998, No: 4/77/216, M. 1756, s.205. Benzer birçok istibdal işlemi için verilen ahkâma örnek olarak bkz; a.e., s.37-38, 9091, 97-98, 168-170, 215-216. Kira ișlemlerine örnek olarak bkz; a.e., s.15, 141; İstanbul Kadı Sicilleri, Üsküdar Mahkemesi, 5 Numaralı Sicil (H. 930-936/M.1524-1530), edit., Coşkun Yılmaz, İstanbul: İSAM Yayınları, 2010, No: 481 , s.277. 
cı olarak vakfı temsil ederler. Bu durumda vakıf, mal sahibi, alacaklı, borçlu, davalı ve davacı gibi hukuki konumlar alır; mütevellinin veya diğer temsilcilerin şahsıyla alakalı herhangi bir şey tahakkuk etmez. Temsilciler, vakıf malları üzerinde kişisel bir hak da talep edemezler. ${ }^{16}$

Hanefi mezhebine mensup hukukçular vakıf vb. kuruluşların belli haklardan yararlanabildiklerini ve belirli durumlarda yükümlülük altına girebildiklerini kabul eder. Zahraa, buna dayanarak Hanefi hukukçularının dolaylı olarak vakıfların onları yönetenlerden farklı ve ayrı bir kişiliğe sahip olduklarını ima ettiğini söyler. Vakıfların kişilikleri, yönetici gerçek kişilerden farklıdır, çünkü gerçek kişi olan insanla tamamıyla aynı değildir; ayrıdır, çünkü vakfın yöneticileriyle bir ilişkisi yoktur. Zahra'ya göre bu tam da tüzel kişilik (juristic personality) kavramıdır. ${ }^{17}$ Burada Zahraa, vakfın onu yönetenlerin ömrüyle sınırlı olmaması; sürekli olması sebebiyle, ayrı bir kişiliğe sahip olduğunu düşünmüş gibidir. Ancak, vakfın mütevelliden bağımsız bir yapı olması onun tüzel kişiliğe sahip olduğu anlamına gelmemektedir. Örneğin günümüz Türkiyesi’nde fakülte dekanları gelip geçici, fakülteler ise süreklidir. Bununla birlikte bu özellik fakülteyi tüzel bir kişi yapmaya yetmez. Fakülteler tüzel kişiliğe sahip değildir; kendisini yöneten dekanlardan farklı bir tüzel kişiliğe (rektörlüğe) bağlıdır. Süreklilik ve bağımsızlık konusuna Timur Kuran da değinmiştir. Kuran’ın da belirttiği gibi, vakıfların yaşam süresi -korporasyonlara benzer biçimde- yöneticilerinin (mütevellinin), çalışanların ve hizmet verdiği kesimlerin varlıklarından bağımsızdır. Kuran, vakfın bu özelliğinin modern şirketlere geçişin başlangıç noktasını oluşturabileceğini öne sürmüştür. Ancak ona göre, vakıfların modern bir şirketin (korporasyonun) aksine özerkliği yoktur. Yazar, özerkliğin yokluğuna gerekçe olarak kurucu tarafından belirlenen değiştirilemez kuralları (vâkıf şartlarını) göstermiştir. ${ }^{18}$

Timur Kuran, aynı dönemlerde ortaya çıkan Orta Doğu vakıf sistemi ile Batı Avrupa korporasyon modelinin temellerini büyük ölçüde Roma Hukuku’ndan aldığını öne sürer. ${ }^{19}$ Ancak bu çıkarım ne hukuk teorisi ve yöntemi ne de hukuk tarihi açısından doğrudur. Hüseyin Naci, henüz 1922 yılında yazdığı makalede bu bakış açısını açık bir şekilde eleştirmiştir. Hüseyin Naci’ye göre, “Onlar [Avrupalı hukukçular] vakf 1 mütalaa ederken garb manzume-i hukukiyesi düsturlarının tesiratından azade kalamayarak şark hukukunu kendi ades-i ilmiyeleriyle müşahade etmiş olduklarından hukuk-i İslamiye nokta-i nazarından bazı hatalara düşmüşlerdir. Vakıf hususunda olduğu gibi diğer birçok mes’elede de bir Avrupa hukuk âlimi için en mühim müşkilat küçükten beri alel umum hukuk hakkında edindiği malumattan tecrit etmekte ve kavanin-i garbiyenin esasatını teşkil eden nokta-i nazara göre değil, İslam hukukunun esâsatına göre muhakeme etmeye muvafik olmaktadır?20 Hüseyin Naci bu yorumuyla, karşılaştırmalı hukuk araştırmacılarına çok mühim bir yöntem dersi verir gibidir. Ona göre İslam Hukuku’nu analiz eden Avrupalı hukukçular tek taraflı bir bakış açı-

16 Köse, “Tüzel Kișilik”, s.229-230.

17 Zahraa, "Legal Personality”, s.202.

18 Kuran, “Azgelişmişliğin Kurumsal Kökenleri”, s.58.

19 Kuran, "Azgelişmişliğin Kurumsal Kökenleri”, s.58.

20 Hüseyin Naci, "Vakfa Dair Bir Tedkik”, Darülfünun Hukuk Fakültesi Mecmuası, 2/12 (Teşrini Sani 1338/Kasım 1922), s.104. 
sıyla, İslam Hukuku’nu kendi teorik çerçevesi ve kanunları açısından değil, Avrupa Hukuku'nun felsefesinden yola çıkarak değerlendirmektedirler. Bu yaklaşım da onları yanlış çıkarımlara sürüklemektedir. Hüseyin Naci, toplumsal ihtiyaçlar benzer olduğu için benzer hukuki düzenlemelerin ve kanunların yapılabileceğini hatırlatarak, bu benzerliğin hiçbir zaman farklı toplumların oluşturduğu kanunların ya da hukuk kurallarının aynı olmasını gerektirmediğini vurgulamıştır. Bu sebeple "İslamiyet'e has bazı müssesatın mahiyetini anlamak içün Roma hukukundan istidalalatta bulunmak hatalı bir yoldan gitmek demektir". ${ }^{21}$ Kisaca hukuk tarihi açısından İslam Hukuku'nu Roma Hukuku'yla bağdaştırmak doğru bir yaklaşım olmayacaktır. İslam ve Avrupa hukuku karşılaştırması yaparken araştırmacıları hata yapmaya sevk eden diğer bir husus; genelde Avrupa hukuk sistemi temel alınarak İslam Hukuku'nun değerlendirilmesidir. Bu yöntemde eşitler arası bir karşılaştırma değil zımni olarak Avrupa Hukuku'na has uygulamaların ve teorik çerçevenin üstün konuma yerleştirildiği modernist bir yaklaşım ortaya çıkmaktadır. Oysa Hüseyin Naci’nin de vurguladığı gibi İslam Hukuku’nu kendi şartları içerisinde değerlendirip, zaman ve mekân (time and space) kıstaslarını da dikkate alarak her iki hukuk rejimini bu bakış açısıyla ele almak gerekir. Bu yolla çağdaş her iki rejimin de benzerlikleri ve farklılıkları eş anlı biçimde gözlenebilecektir.

\section{Osmanlı'da Vakıf İdaresi ve Tüzel Kişilik: Literatüre Bakış}

\section{Vakıf İdaresi}

Vakıflar, İslam ve Osmanlı tecrübesinde çok çeşitli örgütlenmeler içerisinde farklı birimler tarafından idare edilmiştir. Bu toplumlarda, devletin vakıflar üzerindeki idari ve denetim gücü oldukça yüksektir. Bunun en somut göstergesi de merkezi idareye bağlı kadılardır. Bu durum hükümdarın vakıflar üzerinde murakabe (denetim, kontrol) hakkının ötesinde, "daha geniş haklara" sahip olduğunu gösterir. Köprülü’ye göre kadılar, bütün İslam devletlerinde vakıflara nezaret eden görevliler arasındadır. Örneğin Abbasilerde olduğu gibi, Gaznellilerde ve Selçuklularda da vakıf idaresi kadılara bırakılmıştır. Atabeklerde, Anadolu Selçuklularında ${ }^{22}$, Eyyubilerde, Hindistan'da, Afganistan'da ve sonradan hüküm süren diğer muhtelif Türk devletlerinde aynı sistem devam ettirilmiştir. Osmanlılar da önceki Türk devletlerinin vakıf idare sistemini takip etmişlerdir. Şöyle ki Osmanlı döneminde de, sultan vakıflarına vezirler mütevelli veya nâzır olarak tayin edilmiş, kadılar bilhassa hususi vakıfları denetlemiş, bazı dönemlerde payitaht kadısı başka alanlardaki vakıfları teftişten geçirmiş veya çeşitli yerlere müfettişler gönderilmiştir. Köprülü'ye göre, muhtemelen I. Mehmed döneminde (1418 yılından önce) bütün kadılık teşkilâtları bir merkeze bağlanarak Hâkim-ül-hükkâm ünvanıyla bir baş kadı tayin edilmişti. Baş kadı tüm vakıfların denetiminden sorumluydu. Sultan I. Murad ve Sultan Fatih dönemlerinde ise bu görevi kazaskerler yerine getiriyordu. Bunların yanında, sultan vakıfları-

21 Hüseyin Naci, "Vakfa Dair Bir Tedkik”, s.104.

22 Fuad Köprülü, İzzeddin Keykâvûs vakfiyesindeki bir kayda dayanarak, önemli bir saray görevlisi olan üstâdüt-dâr’n sadece hükümdar vakıflarına değil ülkedeki tüm vakıflara nezaret ettiğinden, yani her vakfın mütevellisinin üzerinde genel bir nâzırın varlığından bahseder. Bkz; Fuad Köprülü, "Vakıf Müessesesinin Hukukî Mahiyeti ve Tarihî Tekâmülü”, Vakıflar Dergisi, 2 (1942), s.22. 
nın, nazır sıfatıyla büyük devlet adamları tarafından maiyetlerindeki özel bir teşkilat yoluyla idare edilmesi geleneği devam ettirilmiş, imparatorluk genişledikçe sultan vakıflarının sayısında görülen artış bu teşkilatların sayısına da yansımıştır. Sultan Fatih, I. Selim ve II. Süleyman vakıflarının idaresi sadrazamlara ve Sultan II. Bayezid ile I. Ahmed vakıflarının idaresi ise şeyhülislâmlara verilmişti. Diğer padişahlara ait vakıflar yanında mütevellileri kalmamış olan vüzera ve ricâl vakıflarının mütevelli ve nazırlıkları ise saray görevlilerine veriliyordu. ${ }^{23}$

Burada nazır, "vakıf hükmî şahsı için" mütevelli gibi zorunlu bir organ olmayıp, ihtiyari bir organ niteliğindeydi. Bunun yanında, sadrazam ve şeyhülislam gibi nazırlar vakıf hukuku hakkında yeterli bilgiye sahip olmayabilirdi. Bu durumda, maiyetine vakıf işlerinde uzman olan birini müfettiş olarak tayin ederdi. ${ }^{24}$ Nitekim birçok büyük vakıfta, mütevellilik çocuklara, nazırlık ise sadrazam, şeyhülislam, darüssaade ağası ve İstanbul Kadısı gibi önemli görevlilere verildiğinden, bu nezaretlerin birer müfettişi olur, bunlar her yıl vakıf hesaplarını ${ }^{25}$ ve mütevelli hakkındaki şikâyetleri inceleyerek nazıra bildirirlerdi. Böylece bu tip vakıfların ayrıca kadılar tarafından teftişi yapılmazdı. Bu vakıfların mütevellilerinin tayini ve azli de, bilhassa vâkıfın (kurucunun) çocuğunun ölmüş olduğu vakıflarda doğrudan nazırlara aitti. ${ }^{26}$

Kısaca, Osmanlı vakıflarının idaresinde direkt olarak söz sahibi olanlar aslında vakfın idarecisi olan mütevelli, denetçisi olan nazır ve ayrıca gelirleri tahsil eden câbidir. Bu görevliler yanında, yukarıda belirtildiği gibi kadılar vakıfların idaresinde önemli bir role sahiptir. Ayrıca, başta padişah olmak üzere sadrazam, kazasker, şeyhülislam, defterdar ve diğer görevliler de çeşitli aşamalarda vakfın idaresinde söz sahibi olmuşlardır. Osmanlı idaresi vakıflara ait görevleri merkezden (başkentten) vererek ve bütün vakıfların yılsonu muhasebe raporlarını mahalli kadılar ve Divan-1 Hümâyun yoluyla denetleyerek bu kurum üzerindeki kontrol gücünü asırlarca kullanmıştır. ${ }^{27}$ Osmanlı kadısının, azlini gerektiren susitimalleri ve suçları ortaya çıkan mütevelliyi azletme yetkisi de vardır. ${ }^{28}$

Görüldügü üzere, vakıf idaresinde merkezi eğilimin varlığı Evkaf Nezareti’yle (1826) başlamış değildir. Bilindiği üzere, Osmanlı döneminde devlet (kamu) hizmetleri ile vakıf hizmetleri birbiriyle doğrudan ilişkiliydi. Halkın bayındırlık, eğitim ve sağlık gibi birçok sosyoekonomik ihtiyaçlarını karşılayan vakıflarla ilgili konular, Evkaf Nezareti kuruluncaya kadar Divan'da görüşülürdü. Bu sırada sultan vakıflarının nazırı, darüssaade ağası, Haremeyn vakıfları müfettişi, evkaf muhasebecisi ve mütevelliler hazır bulunurdu. ${ }^{29}$ Osmanlı Devleti’nin en azından 15. yüzyılın ortalarından beri

23 Köprülü, "Vakıf Müessesesi”, 14-16. Bu konuda ayrıca bkz; İlber Ortaylı, Türkiye Diyanet Vakfı İslam Ansiklopedisi, "Kadı (Osmanlı Devleti'nde Kad1)” maddesi, 24, İstanbul, 2001, s.72-73.

24 Onar, İdare Hukukunun Umumi Esasları, 547; İșeri, "Vakıflar”, s.235.

25 Bir örnekle, nezareti Sadrazama ait vakıflardan olan İstanbul'daki Molla Gürani Vakfínın muhasebesi Evkaf Müfettişi tarafından yapıllyor, vakıfla ilgili padişah emirleri/hükümleri yine bu müfettişe gönderiliyordu. Bkz; İstanbul Ahkâm Defterleri, No: 1/148/652, M. 1743, s.36.

26 Köprülü, "Vakıf Müessesesi”, s.22-23.

27 Mehmet İpşirli, “Osmanlı’da Vakıfların Tarihî Gelişmesi”, Sivil Toplum: Düşünce ve Araştırma Dergisi, 4/15 (2006), s.65-66.

28 Onar, İdare Hukukunun Umumi Esasları, s.547; İșeri, "Vakıflar”, s.235.

29 Mustafa Alkan, “Türk Tarihi Araştırmaları Açısından Vakıf Kayıtlar Arşivi”, Vakıflar Dergisi, 30 (2007), s.5. 
merkezi bir kontrol uyguladığı sultani ve büyük ricale ait vakıflar dışında, merkezi kontrolün diğer vakıflara doğru genişletilmesi yönünde periyodik girişimlerde bulunulmuştur. Mısır, Kuzey Afrika, Suriye ve Arabistan'ın fethinden sonra Haremeyn (Mekke ve Medine) vakıfları büyük bir önem kazandı. Bu vakıflara nezaret etmek üzere geniş bir organizasyon oluşturularak önce kapı ağaları sonrasında ise darüssaade ağaları nazır ünvanıyla bu idarenin başına getirildi. 18. yüzyılda ve bilhassa 19. yüzyıl boyunca, vakıf yönetimi, bir seferde on ya da daha fazla vakfı yöneten görevlilerle gerçek bir meslek haline geldi. Bu münferit yöneticilerin yanı sıra, hem taşrada hem de İstanbul'da vakıf idaresi kurumsallaşmış ve sadrazam, şeyhülislam, Haremeyn Müfettişi ve Kaptan Paşa makamları gibi kalıcı pozisyonlarla ilişkilendirilmişti. Bilhassa Sultan Selim III döneminde ve ardından 1826'da Yeniçeri Ocağı'nın kapatılmasından sonra, merkezi idare önemli vakıfları kontrolü altına almayı başarmıştı. İstanbul'da 19. yüzyılın başlarına gelindiğinde darüssaade ağaları, sadrazamlar ve şeyhülislamların nezaretlerine İstanbul, Galata, Üsküdar ve Eyüp kadıları ile kaptan paşalar, yeniçeri ağaları, sekbanbaşı ve bostancıbaşılar gibi merkezi görevlilerin nezaretleri de eklenmiş; müstakil birçok vakıf nezareti ortaya çıkmıştı. Evkaf Nezareti kuruluncaya kadar vakıflar bu teşkilatlar tarafından mütevelli ve nazırlar yoluyla yönetildi. İşte merkezi idarenin nezareti kurma amaçlarından biri de bu durumun sebep olduğu suistimalleri engellemekti. Nihayet Yeniçeri Ocağı’nın kapatılmasından sadece birkaç ay sonra Evkaf Nezareti kuruldu ve birkaç yıl içerisinde yukarıda sayılan ricale ait etkili ve büyük vakıflar nezarete devredildi. Böylece Tanzimat Dönemi'nin eşiğinde, Evkaf Nezareti’nin kurulmasıyla birlikte vakıflar merkezi idarenin doğrudan kontrolü altına alınmış oldu. ${ }^{30}$

\section{Osmanlı Vakıflarının Tüzel Kişiliği Sorunu}

Vakıf kurumunun hukuki özelliklerinin başında vakfın sürekliliği ve ebediliği gelir. Ardından vakfın temlik ve temellük edilememesi özelliği anılmaktadır. Vakfın bağlayıcılık özelliği ise faaliyetler konusunda vakfetme iradesinden dönülemeyeceği anlamına gelir. Ertem’e göre Osmanlı vakıflarının tüzel kişiliği vardır ve bu dört nitelik vakfı diğer benzer kurumlardan farklı kılmaktadır. ${ }^{31}$ Barkan da "kendilerine mahsus hususî bir statüye tâbi olan” vakıfların "idarî-malî bakımdan muhtâriyeti” (özerkliği) olduğunu yazmıştır. ${ }^{32}$ Fikret Eren'e göre, "Osmanlı ve Türk Medeni Hukuklarında vakıf, kavram olarak ayn anlamı ifade etmektedir"; bu sebeple, Osmanlı dönemi vakıfları tüzel kişiliğe, daha açık bir ifadeyle idari ve mali özerkliğe sahip olan mal topluluklarıdır. ${ }^{33}$ Vakıf yapılan mal, vâkıfın servetinden çıkar ancak başka bir kişi veya kuruluşun mülkiyetine de girmez. Öztürk, vakfın bu temel özelliğini dikkate alarak vakfın, kanun önünde kendisini temsil ettiğini, bu yüzden de tüzel kişiliğe

30 Köprülü, "Vakıf Müessesesi", s.23; Randi Deguilhem, The Encyclopedia of Islam, 2nd edition, "Wakf, In the Ottoman Empire to 1914”, XI, Leiden: Brill, 2002, s.88-90; Hâtemî, Medenî Hukuk Tüzel Kişileri, s.549-567.

31 Adnan Ertem, “Osmanlıdan Günümüze Vakıflar”, Vakıflar Dergisi, 36 (2011), s.28.

32 Ömer Lûtfi Barkan, "Şehirlerin Teşekkül ve İnkişafı Tarihi Bakımından: Osmanlı İmparatorluğunda İmaret Sitelerinin Kuruluş ve İşleyiş Tarzına Ait Araştırmalar”, İstanbul Üniversitesi, İktisat Fakültesi Mecmuası, 23/1-2 (1963), s.295-296.

33 Fikret Eren, “Osmanlı Dönemi Vakıfları”, V. Vakıf Haftası Kitabı içerisinde, Ankara: Vakıflar Genel Müdürlüğü Yayını, 1988, s.195-196, 198. 
sahip olduğunu kabul etmiştir. ${ }^{34}$ Akgündüz, mütevellinin vakıfla ilgili tasarruflar bakımından "vakıf hükmî şahsiyetinin vekili” yani vakıf tüzel kişiliğinin temsilcisi olduğunu yazmıştır. Mütevelli, zilyedi altındaki vakıf malları içinse yed-i emânet niteliğine sahiptir. ${ }^{35}$

Vakıfların tüzel kişilik tartışmasını dolaylı olarak TBMM zabıt ceridelerinden takip edebiliriz. 1926 tarihli Medeni Kanun'dan sonra 1935 yılında "eski vakıflar" için hazırlanan kanun görüşmelerinde, mecliste söz alan Kocaeli mebusu Salâh Yarg1, Osmanlı vakıflarının tüzel kişiliğe (hükmî şahsiyete) sahip olduğunu ifade etmiştir. ${ }^{36}$ Bununla birlikte, aynı oturumda görüşülen Vakıflar Kanunu layihasının gerekçesindeki “...yirmi sene evveline gelinceye kadar vakıflar için bir hükmî şahsiyet bile kabul edilmemesidir. Böyle bir esas kabul edilmemesidir ki vakıfları mütevellilerin malı haline getirmiş ve çoğu saray bendegânı olan mütevelliler bunları doğrudan doğruya ve hangi bir sebeble buna muvaffak olamazlarsa bir yolunu bularak mahkemeden müsaade istihsal ile yemişler, vakıfları bu günkü acıkl hale getirmişlerdir" yorumu dikkat çekicidir. Özetle, kanun gerekçesinde Cumhuriyet'in ilanına kadar aslında vakıflara tüzel kişilik hakkı tanınmadığı, bu hakkın 1935 yılında bahsi geçen bu kanunla verildiği belirtilmektedir. ${ }^{37}$

Osmanlı vakıflarının hukuki konumuyla ilgili diğer bir konu, bu vakıfların kamu hukuku tüzel kişisi mi, özel hukuk tüzel kişisi mi olduğudur. Sıddık Sami Onar’a göre Osmanlı vakıfları, Cumhuriyet Dönemi Medeni Hukuku'nda yer alan vakıfların aksine, bir kamu hukuku müessesesiydi. Bu görüşü Onar’’n cümleleriyle ifade edersek; "vakıf mahiyet ve menşei itibariyle daima bir hususi hukuk müessesesi halinde kalmakla beraber geçirdiği istihalelerle idari bir mahiyet almıya başlamış ve nihayet bir amme müessesesi şeklinde devlet teşkilatı içine girmiştir" ${ }^{38}$ Ahmet İşeri de aynı bakışla, sultan vakıflarının, sadrazam, şeyhülislam ve kapı ağası gibi üst düzey görevliler tarafından idare edilmeleri sebebiyle, "zamanla devlet idare teşkilatı içine" girdiğini yazmıştır. ${ }^{39}$ Hâtemî de bu merkezi görevlilerin nezaretlerindeki vakıfları "yarı resmi kuruluşlar” olarak nitelendirir. ${ }^{40}$ Özsunay’a göre ise eski hukukumuzda tüzel kişilik sadece vakıflara tanınmıştır. Vakıf mallar da kamu malı sayılmış, vakıflar kamu kişiliği olarak kabul edilmiştir. ${ }^{41}$

Onar’a göre vakıfların “amme hükmi şahsı mahiyeti hukuk tarihimize mahsus bir hu-

34 Nazif Öztürk, “XIX. Yüzyılda Osmanlı İmparatorluğu’nda Sanayileşme ve 1827'de Kurulan Vakıf İplik Fabrikası", Vakıflar Dergisi, 21 (1990), s.28.

35 Ahmet Akgündüz, İslâm Hukukunda ve Osmanlı Tatbikatında Vakıf Müessesesi, Ankara: Türk Tarih Kurumu Yayını, 1988, s.244-257.

36 TBMM Zabıt Ceridesi, C. 4, 33. İnikad, 3 Haziran 1935, erişim 30 Haziran 2018, https://www.tbmm.gov.tr/ tutanaklar/TUTANAK/TBMM/d05/c004/tbmm05004033.pdf, s.24.

37 TBMM Zabıt Ceridesi, C. 4, 33. İnikad, 3 Haziran 1935, içerisinde "4 Teşrinievvel 1926 Tarihinden Evvel Mevcud Olan Vakıflar Hakkında Tatbikat Kanunu Lâyihası Esbabı Mucibesi”, Sıra Sayı: 124-2, 12.6.1932, s.3, 13. Bu yoruma Hüseyin Hâtemî de dikkat çekmiştir. Bkz; Hâtemî, Medenî Hukuk Tüzel Kişileri, s.57.

38 Onar, İdare Hukukunun Umumi Esasları, s.538.

39 İşeri, "Vakıflar", s.236.

40 Hâtemî, Medenî Hukuk Tüzel Kisilleri, s.330.

41 Ergun Özsunay, Medenî Hukukumuzda Tüzel Kişiler, Tüzel Kişilerin Genel Teorisi-Dernekler-Vakıflar, 3. baskı, İstanbul: İ.Ü. Hukuk Fakültesi Yayınları, 1974, s.14. 
susilik sayllabilir: Garp hukukunda vakıf daima bir husus hukuk müessesesi olarak kalmış"tır. ${ }^{42}$ Ancak bu genelleme tüm Batı ülkeleri için yapılamaz. Avrupa'da birbirinden ayrı birçok vakıf çeşidi ortaya çıkmışıır; kamu hizmetleri vakıfları, kilise vakıfları, aile vakıfları, büyük sanayi bölgelerinde toplumsal hizmetler için oluşturulmuş vakıflar, araştırma enstitülerinin vakıfları ve komün vakıfları bunlardan bazılarıdır. Avrupa'da vakıflar ya müstakil kuruluşlardır ya da kamu kuruluşlarının altında hizmet vermektedir. Ancak kamu kuruluşlarının sorumluluğundaki bu vakıflar (Osmanlıdaki mazbut vakıflar ${ }^{43}$ gibi) kurucularının amaçlarına göre yönetilmek zorundadırlar. Anglosakson ülkelerinin hemen her yerinde de kamu hizmeti yapan "umumî vakıflar" yer almaktadır. Bunların yanında, Almanya’da tüzel kişiliğe sahip kent idareleri, 13. yüzyılın sonuna doğru özel vakıfların idarelerini ele geçirmişlerdir. Böylece ortaya çıkan "beledî vakıflar" asırlarca sağlık ve sosyal yardım hizmetlerini yerine getirmişlerdir. ${ }^{44}$ Ayrıca Hâtemî, Almanya'da Katolik ve Protestan Kiliselerinin birer özerk (otonom) kamu hukuku tüzel kişileri olduğunu yazmıştır. ${ }^{45}$

$\mathrm{Bu}$ tartışmayı Osmanlı'daki vakıf türlerine taşırsak; Akgündüz, gayrisahih/irsadi ${ }^{46}$ vakıfların, miri arazi hükümlerine tâbi olduğunu belirterek, bu vakıfların mahiyeti itibariyle bir kamu hukuku tahsisi olduklarını öne sürmüștür. Bunların çoğunluğu da mazbut vakıflardır. Müstesna vakıfların tamamının da bu tip gayrisahih vakıflar olduğunu hatırlatan Akgündüz, 1858 tarihli Arazi Kanunnamesi’nde, miri arazi kadar vakıfların hükümlerinin de düzenlenmiş olduğunu belirtmiştir. ${ }^{47}$ Hâtemî de, gayrisahih vakıfların özel hukuk vakfı olmadığı görüşündedir. Ona göre gayri sahih vakıfların "tamamen hususi bir müessese" olduğu tartışılır bir konudur. Nitekim bir padişahın cami veya medrese yaptırmasını, aslında devlet hazinesine ait olan miri arazinin vergi gelirini de bu vakfa tahsis etmesini hayırseverlik olarak değil, "iyi bir kamu hukuku işlemi" olarak yorumlamıştır. ${ }^{48}$

42 Onar, İdare Hukukunun Umumi Esasları, s.538.

43 Mazbut vakıflar, genel anlamda mütevellileri mevcut olduğu halde, Evkaf Nezareti’nin bu mütevellilere maaş bağlayıp idaresini doğrudan doğruya zapt etmiş olduğu vakıflardır. Bunlara, Köprülü ve Sokullu vakıfları örnek gösterilebilir. Bkz; İşeri, "Vakıflar”, s.237. Diğer mazbut vakıflar ise padişah adına Evkaf Nezareti’nin yönettiği ve mütevellisi olmadığı için yine nezaret tarafından yönetilen vakıflardır. 1935 yılındaki Vakıflar Kanunu’yla birlikte mazbut vakıfların kapsamı genişletilmiştir. Örneğin, kanunen veya fiilen bir fonksiyonu kalmayan vakıflar ile mütevelliliği vakfedenin soyundan olanların dışında başka kişilere şart edilmiş olan vakıflar da mazbut vakıf sayılmıştır. Ayrıntı için bkz. Hâtemî, Medenî Hukuk Tüzel Kişileri, s.365-366, 399, 441-445; Onar, İdare Hukukunun Umumi Esasları, s.552-553.

44 Ernst Reuter, "Beledi Vakıfların Modern Şehir İdaresindeki Ehemmiyetleri”, çev., Coşkun Üçok, İ.Ü. İktisat Fakültesi Mecmuast, 3/3-4 (1942), s.329-331.

45 Hüseyin Hâtemî, "Vakıf Kurumuna Hukuk Tarihi Açısından Genel Bir Bakış", İstanbul Üniversitesi Hukuk Fakültesi Mecmuasi, 55/4 (1997), s.122.

46 İrsadi vakıflar diğer bir adıyla tahsisat kabilinde vakıflar, miri arazinin kuru mülkiyeti (rakabesi) yine devlette kalmak şartıyla, sadece gelirlerinin padişah veya onun yetkili kıldığı bir kişi tarafından kamu yararı (eğitim, sağlık ve sosyal güvenlik gibi kamu hizmetleri) için belirli kişilere tahsis edilmesiyle kurulur. Bkz; Akgündüz, Vakıf Müessesesi, s.423-444. Sahih vakıflar ise kişinin kendi mülkünü vakfetmesiyle oluşur ki İslam Hukuku’na göre kastedilen esas vakıflar bunlardır. Kendisine su değirmeni, bağ ve çiftlik yeri "hibe ve temlik ve yedine mülknâme-i hümâyûn" verilen kişinin bu yerleri vakfetmesi örneği için bkz; İstanbul Ahkâm Defterleri, No: 2/142/488, M. 1746, s.90.

47 Akgündüz, Vakıf Müessesesi, s.444-453.

48 Hâtemî, Medenî Hukuk Tüzel Kişileri, s.67, 69, 328-329. 
Hâtemî, Vakıflar Genel Müdürlüğ̈̈’nün (VGM) yönetimindeki mazbut vakıfların bir zamanlar idare hukukçuları tarafından kamu hukuku tüzel kişiliği olduğunu kabul ettiklerini ${ }^{49}$ hatırlatarak, Yargıtay’nn bu vakıfların Özel Hukuk tüzel kişiliği olduğu sonucuna vardığını belirtmiştir. Ancak burada ortaya çıkan önemli bir hukuki sorunu da gündeme taşıyarak, mazbut vakıfların kendilerine ait bir organları olmadığını; bu özel hukuk tüzel kişiliğinin, bir kamu hukuku tüzel kişiliği olan VGM’nin vesayeti altında olduğunu vurgulamıştır. Bu sebeple, "idari vesayet” iki kamu tüzel kişiliği arasında söz konusu olduğundan, Hâtemîye göre mazbut vakıflarla VGM arasındaki bu ilişki "sui generis" bir özel hukuk vesayeti olarak görülebilir. ${ }^{50}$

Hâtemîye göre, Osmanlı batılılaşma döneminde devlet hazinesinden karşılanan kamu kurumları meydana getiriliyor, bunların vakıf olduğundan bahsedilmiyordu. Bu sürecin sonunda devlet tüzel kişiliğinden bağımsız tüzel kişiliği olan belirli kamu hizmetlerine malvarlığı özgülenmesi ile oluşan kamu kurumları doğmuştur. II. Mahmud döneminde vakıf hukuki görünümü içinde bu hizmet bir özerklik ve bağımsızlık kazanacağından, kamu kurumlarının ayrı tüzel kişilik kazanabilmesi için elverişli birikim vardır. Hâtemî, II. Mahmud döneminde oluşturulan ve ileride üniversite türünde kamu tüzel kişiliğinin doğumuna yol açacak olan yeni mektepler ile Encümen-i Daniş’i bu kuruluşlara örnek olarak vermiştir. ${ }^{51}$

Görüldüğü üzere, hukukçular ve tarihçiler Osmanlı vakıflarının tüzel kişiliğini tartışmaya dahi açmamışlar; yalnızca özel hukuk tüzel kişisi mi yoksa kamu tüzel kişisi mi olduğunu sorgulamışlardır. Bu yüzden literatürde vakıfların tüzel kişiliğinin varlığına dair genel anlamda bir görüş birliği hâkim olmuştur. Belki de bu genel kabul sebebiyle konu hakkında henüz derinlikli hukuki etütler yapılmamıștır. Timur Kuran ise İslam ve dolayısıyla Osmanlı vakıflarının, çağdaşları olan Avrupa’daki korporasyonların-ortaklıkların aksine tüzel kişiliği olmadığını öne sürmüştür. ${ }^{52}$ Murat Çizakça da son çalışmalarında literatürdeki mevcut bilgiler ışığında, İslam-Osmanlı vakıflarının Avrupa'daki vakıflara nazaran tüzel kişiliğe sahip olmadıkları kanaatine varmıştır. ${ }^{53}$ Tüzel kişilik tartışmasına girmeden konuya değinen Nil Sarı, vakıf kuruluşu olan darüşşifaların kendi vakfiyeleri doğrultusunda idare edildiğini, ancak bu hastanelere yapılan tayinlerin ve hastanelerin işleyişinin sarayın yönetim düzenine tâbi olduğunu hatırlatmıştır. ${ }^{54}$ Aşağıda, Osmanlı vakıflarının tüzel kişiliğinin varlığı-

$49 \mathrm{Bu}$ idare hukukçuların en önemlilerinden biri Sıddık Sami Onar'dır. Onar’a göre, 1935 yılında yayınlanan Vakıflar Kanunu gereği Vakıf Umum Müdürlüğ̈̈nün idaresi altındaki mazbut vakıflar tüzel kişiliğe sahip bir "amme müessesesi”dir. Müdürlüğün denetimi altındaki mülhak vakıflar ise "amme müessesesi” değildir. Bkz; Onar, İdare Hukukunun Umumi Esaslarl, s.554-555.

50 Hâtemî, "Vakıf Kurumu", s.121.

51 Hâtemî, Medenî Hukuk Tüzel Kişileri, s.68-69.

52 Timur Kuran, Yollar Ayrılırken, Ortadoğu’nun Geri Kalma Sürecinde İslam Hukukunun Rolü, çev., Nurettin Elhüseyni, İstanbul: Yap1 Kredi Yayınları, 2012, s.143-150, 165, 169, 361; Timur Kuran, "The Provision of Public Goods under Islamic Law: Origins, Impact, and Limitations of the Waqf System”, Law \& Society Review, 35/4 (2001), s.842.

53 Çizakça, "Waqf and Reforming”, s.4-5.

54 Nil Sarı, Türkiye Diyanet Vakfı İslam Ansiklopedisi , “Tip (Osmanlı Dönemi)” maddesi, 41, İstanbul, 2012, s.101. Darüşşifa personelinin tayinleri, genellikle tabib-i evvelin mütevelliye, mütevellinin de hekimbaşına teklifi ve onun da arzıyla sadrazam tarafından yapılırdı. Bkz; Başbakanlık Osmanlı Arşivi (BOA), İE.SH 1/24, M. 1686; BOA, İE.EV 13/1581, M. 1686. Bu konuda ayrıca bkz; Yasin Yılmaz, "Kanunî Vakfiyesi ve Süleymaniye Külliyesi (Eğitim, Kültür ve Sosyal Yönü-Başlangıçtan 1600’e Kadar)”, Doktora Tezi, Ankara Üniversitesi, 2002, s.148- 
nı vakıf türleri itibariyle tartışmaya çalışacağız.

\section{Tüzel Kişilik Tartışmasında Hangi Vakıflardan Bahsediyoruz?}

Literatürde vakıfların tüzel kişiliği konusundaki kanaatler veya çıarımlar çoğunlukla tüm vakıfları içerisine alan bir genellemeye dayanmakta, vakıfların hukuki konumları çoğunlukla vakıf türleri dikkate alınmadan yorumlanmaktadır. Oysa vakıfların tüzel kişiliğinin varlığı ve kamu hukuku-özek hukuk kişiliği tartışmaları, vakıfların türleri ve birbirlerinden farklı nitelikleriyle birlikte tartışılmalıdır. Vakfın türü, tüzel kişiliğin zayıflı̆̆ ve güçlülügü yanında kamu hukuku tüzel kişiliğinin mi yoksa özel hukuk kişiliğinin mi ağır bastığı hakkında daha açık fikir verecektir.

Kanaatimizce, sultan vakıfları ile büyük devlet adamlarının kurduğu vakıfların tüzel kişiliği fiiliyatta diğer özel vakıflar karşısında daha zayıf kalan özelliklere sahiptir. Zira yukarıda vakıf idaresi konusunda bahsedildiği üzere, bu tip vakıfların idaresinde ve denetiminde merkezin doğrudan müdahaleleri söz konusudur. Daha spesifik olarak; Pantık’n belirttiği üzere, idaresi ve denetimi bir nezarete veya makama terk edilen, sultan ve devlet adamlarına ait vakıflarda vakfı temsilen sadece mütevellinin izni yeterli değildir. Pantık, Evkaf-1 Hümayun Müfettişliği Mahkemesi kayıtlarından, bu tür vakıflar için yapılan icâreteyn sözleşmelerinde mütevellinin yanında sorumlu nazırın veya Evkâf-1 Haremeyn Nezareti'ne bağlı vakıflarda yetkili Evkâf-1 Haremeyn Müfettişinnin olurunun gerektiğini tespit etmiştir. Bazı sultan vakıflarında ise bizzat padişahın iradesi (onayı) gereklidir. ${ }^{55}$ Yazarın birincil kaynaklardan yola çıkarak ulaşıı̆ı diğer çıkarımlara göre, merkezin denetimdeki vakıfların taşınmazlarından alınan muacceleler darüssaade ağasının denetimindedir. Bu uygulama, Tanzimat sonrasında da büyük oranda devam etmiştir. Oysa "sıradan insanların kurdukları" vakıflarda düşük miktarlı alınan muaccelelerde mütevelli - büyük vakıflara nazarangeniş bir yetkiye sahiptir. Bu tür vakıflarda muacceleler, bazı örneklerde vakıf geliri fazlası olarak kurucunun çocukları arasında taksim edilmiştir. Ayrıca bu gelir fazlasının, yeni akar satın alımı veya para vakfı kurmada veya başka yatırım amaçlarında kullanılmak üzere vakfın asıl gelirine eklendiği de olmuştur. ${ }^{56}$

Osmanlı vakıf hukukuyla ilgili en önemli kırılma noktalarından biri Tanzimat'ın eşiğinde yaşanmıştır. 1826 yılında Evkaf Nezareti’nin kurulmasıyla birlikte temel anlamda ortaya iki farklı vakıf türü çıkmıştır. Nezaretin doğrudan nazır sıfatıyla denetim-kontrolüne bağlı olan vakıflara "mülhak vakıflar" denilmiștir. Bunlar, vakfiyelerinde şart koşulduğu biçimde, kendi mütevellileri tarafından idare edilirler. İşeri’ye göre, burada mütevelli Evkaf Nezareti tarafından tayin edilmediğinden ve mülhak vakıf doğrudan nezarete bağlı olmadığından bu vakıfların idaresi müstakildir. "Mazbut vakıflar" ise doğrudan Evkaf Nezareti tarafından idare edilir. ${ }^{57}$ Mülhak

150. Vakıf görevlilerinin ücretlerinin artı̧̣ı, vakıf binalarının tamir yöntemi vs. idari-mali kararları/onayları yine merkezi idare verirdi. Bkz; BOA, İE.SH 2/180, M. 1719; İstanbul Ahkâm Defterleri, s.87, 141, 241, 205, 254.

55 Ramazan Pantık, "Osmanlı'da İcâreteyn Uygulaması Hakkında Yeni Değerlendirmeler", Vakıflar Dergisi, 48 (2017), s.79-80.

56 Pantık, "Osmanlida İcâreteyn", s.93.

57 İșeri, "Vakıflar", s.239. 
vakıfların her biri "hükmî şahsiyete" (tüzel kişiliğe) sahiptirler"58; gerçek kişiler gibi hukuki işlemler yapabilir, alacaklı veya borçlu olabilirler, fiillerinden ve sözleşmelerinden bizzat sorumlu olup, borçlarını da kendi gelirlerinden/mallarından öderler. Mazbut vakıflar ise bu haklara sahip değildir; bu vakıfların her birinin fiillerinden, işlemlerinden ve borçlarından Evkaf Nezareti (Cumhuriyet'le birlikte Vakıflar Genel Müdürlügü -1924) sorumludur. ${ }^{59}$ Dolayısıyla bizce mazbut vakıfların tüzel kişiliği konusu tartışmalıdır. Hâtemî de mazbut vakıfların zamanla "ferdiyet çizgilerinin" belirsizleştiğini Evkaf Nezareti’nin “tüzel kişiliği” içerisinde eridiklerini yazmıştır. ${ }^{60}$ Ancak bazı yazarlar mazbut vakıfların da tüzel kişiliğe sahip olduğu kanaatindedirler. Örneğin Onar, mazbut vakıfların aralarında hukuki bir bağ ve birlik olmadığı ve her birinin ayrı ayrı tüzel kişilikleri olduğu görüşündedir. ${ }^{61}$ Akgündüz, Evkaf Nezareti’nin mazbut vakıflar üzerinde "mansub mütevelli" konumunda olduğunu belirterek, bu idari tasarrufa rağmen mazbut vakıfların tüzel kişiliğinin devam ettiğini öne sürmüştür. ${ }^{62}$

Bilindiği üzere 1935 yılında yayınlanan Vakıflar Kanunu’nda mazbut vakıfların VGM altında "kül halinde" ${ }^{63}$ yani bir bütün halinde tüzel kişi olduğu ifade edilmiştir. Bu tek tüzel kişilik de VGM tarafından idare ve temsil edilir; mazbut vakıfların tüzel kişiliği bu müdürlüğün kişiliği içerisindedir. ${ }^{64}$ Fikret Eren, bu yaklaşımı son derece yanlış bularak; "Bu hukuk dışı bir ifadedir...Tüzel kişilik kül halinde olmaz... Tüzel kişi ferdidir, otonomdur, diğerlerinden ayrıdır, bağımsızdır...bu lafın kaldırılması lazımdır...gülünç bir kavramdır... Her mazbut vakıf, bağımsız bir tüzel kişidir” yorumunu yapmıştır. ${ }^{65}$

\section{Şer’iye Sicillerine Kısa Bir Bakış}

Osmanlı vakıflarının tüzel kişiliğe sahip olup olmadıklarını test etmek için en güvenilir birincil kaynaklardan biri şer'iye sicilleridir. Mahkeme kayıtları, bilhassa sıra-

58 Mülhak vakıfların diğer bir çeşidi cemaat vakıflarıdır. Osmanlı döneminde, gayrimüslimlerin İslam Hukuku’na göre vakıf kurma imkânları teorik olarak vardır. Bilhassa 19. yüzyılda Müslümanların vakıfları gibi vakfiyeleri düzenlenmiş ve mahkeme yoluyla tescil edilmiş vakıflar da vardır. Bununla birlikte gayrimüslim tebaa, ayrı bir kişiliği olan vakıf yerine, genellikle kendi cemaatlerinin "manevî şahsiyeti lehine yükümlü bağışlama” yapmayı tercih etmişlerdir. Ayrıntı için bkz; Hâtemî, "Vakıf Kurumu”, s.121-122.

59 Onar, İdare Hukukunun Umumi Esasları, s.554; İşeri, "Vakıflar”, s.260.

60 Hâtemî, Medenî Hukuk Tüzel Kişileri, s.340.

61 Onar, İdare Hukukunun Umumi Esasları, s.549.

62 Akgündüz, Vakıf Müessesesi, s.286-288.

63 Vakıflar Kanunu (2762 Sayılı), md: 6, erişim 1 Temmuz 2018, http://www.resmigazete.gov.tr/arsiv/3027.pdf. Bu kanunun gerekçesiyle birlikte yayınlanan 20.05.1935 tarihli Adliye Encümeni mazbatasında kül halinde tüzel kişilik tanımlamasına gerekçe olarak şu ifadeler yer almaktadır: "umum müdürlük tarafından temsil olunacağına masraf, gelir ve borç noktasından bir bütün teşkil edeceklerine göre her birinin hukukî mânada ayrı bir şahsiyet olarak kalmaları doğru olmayib her biri gayelerine ve şartlarına göre idare edilseler bile bu takyid mevcud bir hükmî şahsiyetin salâhiyetlerini takyid [şartla bağlama] ve tahdid etmek [sınırlamak] olacağından umum müdürlüğün idare ettiği vakıfların bir kül halinde tek hükmî şahsiyet sayılması daha doğru olacağı fikri üstün geldi ve altıncı madde bu esasa göre yeniden yazıldı”. Bkz; TBMM Zabıt Ceridesi, C. 4, 33. İnikad, 3 Haziran 1935, içerisinde "4 Teşrinievvel 1926 Tarihinden Evvel Mevcud Olan Vakıflar Hakkında Tatbikat Kanunu Lâyihası ve Geçen Devre Adliye Encümeni Mazbatasile Maliye, Dahiliye ve Adliye Encümenleri Mazbataları”, Sıra Sayı: 1242, s.13.

64 Onar, İdare Hukukunun Umumi Esasları, s.553, 555.

65 Fikret Eren, "Vakıf Mevzuatının Aksayan Yönleri Semineri Paneli”, VII. Vakıf Haftası (5-7 Aralık 1989), haz., İ. Ateş, S. Bayram, M. Narince, Ankara: Vakıflar Genel Müdürlüğü, 1990, s.169. 
dan insanların kurdukları nispeten küçük çaplı vakıflar ile aile vakıflarının hukuki konumlarıyla ilgili önemli bilgiler sunmaktadır. ${ }^{66}$ Bu bağlamda, dava konuları, kararlar ve davaya taraf olan kişilerden yola çıkarak vakıfların tüzel kişiliği konusunda bazı çıkarımlarda bulunabiliriz.

Vakfın tüzel kişiliğinin olup olmadığına dair kıstaslar olarak vakfı temsil eden ve faaliyetlerini yürüten bir organının olması, mal varlığının olması, vakfın hak ve fiil ehliyetinin olması ve olumsuz fiil karşısında sorumlu olması gibi önemli unsurlar sayılabilir. Bu minvalde şer’iye sicillerinden çeşitli örneklerle, Osmanlı vakıflarının bu kıstasları karşılayıp karşılamadığını irdeleyerek, vakıfların tüzel kişiliği hakkında daha sağlıklı yorumlarda bulunabiliriz. Tüzel kişiliğin varlığ kriterlerden biri hak ehliyeti içerisinde anılan davalı ve davacı olabilme şartıdır. Osmanlı vakıfları mahkemelerde, vakfın en önemli organı olan mütevelli tarafından, bazı örneklerde de nazır ${ }^{67}$ ve bazen de mütevelli ve nazır tarafından birlikte temsil edilirdi. ${ }^{68}$ Örneğin 1618 yılında İstanbul Suriçi İskender Paşa Mahallesi’nde evini vakfeden bir kişi kadıya başvurmuş İmam-1 Azam Ebu Hanefi'nin vakıf hakkındaki "gayri lazımdır" (yani vakıf bağlayıcı değildir ${ }^{69}$ ) görüşünü öne sürerek; vakıftan caydığını belirtmiş ve vakfettiği malvarlığını geri istemiştir. Mütevelli ise "Ebu Yusuf ve İmam Muhammed b. Hasan eş-Şeybani’ye göre "sıhhatin lüzumdan ayrılmayacağıı” ileri sürerek vakfı geri vermeyi kabul etmemiştir. Bunun üzerine bahsi geçen vâkıf ve vakıf mütevellisi davacı ve davalı olmuşlardır. Sonuçta mahkeme "vakıf lehine" karar vermiştir. Böylelikle "vakıf lazım, müebbed ve muhalled hale" gelmiștir. ${ }^{70}$ Diğer bir sicil örneğinde yer alan “mütevelli olan Ali Subaşı b. Abdullah meclis- $i$ şer'- $i$ şerifde Mustafa Bey b. mahzarında üzerine da’va edip” ifadesi”71, mütevellinin vakıf adına davacı olduğunu göstermektedir.

66 Vakıfların idari işleyişi, hukuki konumları ve idari-mali işlemleriyle ilgili, şer'iye sicillerindeki gibi, önemli bilgiler sunan diğer bir kaynak -çeşitli konular için padişah emirlerini içeren- Vilayet Ahkâm Defterleri’dir. Bu kayıtlar merkezi idarenin tüm vakıf türleri üzerindeki “idari vesayet” gücünü açıkça göstermektedir. Ayrıntı için bkz; İstanbul Ahkâm Defterleri.

67 Üsküdar Mahkemesi, 5 Numaralı Sicil, No: 481, s.277.

68 İstanbul Kadı Sicilleri, Rumeli Sadareti Mahkemesi, 21 Numaralı Sicil (H. 1002-1003/M.1594-1595), edit., Coşkun Yılmaz, İstanbul: İSAM Yayınları, 2011, No: 43, s.87-88.

69 Vakfın bağlayıcılığı hakkında bir çalışma için bkz; Ahmet Hamdi Furat, "İslam Hukukunda Vakıf Akdinin Bağlayıcılı̆̆ı.” İstanbul Üniversitesi İlahiyat Fakültesi Dergisi, 27 (2012), s.68-82.

70 İstanbul Kadı Sicilleri, İstanbul Mahkemesi, 3 Numaralı Sicil (H. 1027/M. 1618), edit., Coşkun Yılmaz, İstanbul: İSAM Yayınları, 2010, No: 486, s.335-336. Benzer örnek olaylar için bkz; a.e., No: 40, s.82-83; No: 532, s.362-363. Ayrıca bkz; "sıhhat ve luzum kavlini tercih ederek vakf-ı mezburun sıhhatine ve lüzumuna hükmetti. Böylelikle vakıf, satılamaz, rehnedilemez, temlik edilemez, mirasa konu olmaz şekilde sahih ve lazım bir vakıf haline geldi", İstanbul Kadı Sicilleri, Üsküdar Mahkemesi, 84 Numaralı Sicil (H. 999-1000/M. 1590-1591), ), edit., Coşkun Yılmaz, İstanbul: İSAM Yayınları, 2010, No: 80, s.127-128. Bu tip cayma davalarının çoğu aslında vakfın dokunulmazlığının tescil edilmesi amacıyla şeklen yapılmıştır. Mütevellinin vakıf adına davalı olduğu bir örnek olay için bkz; Rumeli Sadareti Mahkemesi, 21 Numaralı Sicil, No: 335, s.306. Mütevellinin vakıf adına davacı olduğu örnekler için bkz; İstanbul Kadı Sicilleri, Galata Mahkemesi, 90 Numaralı Sicil (H. 1073-1074/M. 1663), edit., Coşkun Yılmaz, İstanbul: İSAM Yayınları, 2012, No: 255, s.218; İstanbul Kadı Sicilleri, Eyüb Mahkemesi (Havâss-1 Refîa), 90 Numaralı Sicil (H. 1090-1091/M. 1679-1680), edit., Coşkun Yılmaz, İstanbul: İSAM Yayınları, 2010, No: 532, s.441; İstanbul Kadı Sicilleri, Bâb Mahkemesi, 54 Numaralı Sicil (H. 1102/M. 1691), edit., Coşkun Yılmaz, İstanbul: İSAM Yayınları, 2011, No: 4, s.52.

71 İstanbul Mahkemesi, 3 Numaralı Sicil, No: 148, s.142-143. Bu genel ifadenin yer aldığı çok sayıda örnek arasından seçtiğimiz şu davalara bkz; Galata Mahkemesi, 90 Numaralı Sicil, No: 255, s.218; Üsküdar Mahkemesi, 84 Numaralı Sicil, No: 209, s.181-182. 
Vakıflarla ilgili başka işlemler için de vakfın temsilcisi olarak mütevelli hazır bulunurdu. Örneğin Üsküdar'da Selman Ağa Zaviyesi vakfından iki kervansaray ve bir dükkânın kiralanması bahsinin sicile kaydında vakfı temsilen mütevellinin tasdiki/ onayı alınmıştır. ${ }^{72}$ Mütevelliler vakıf kurucular aleyhine de vakıf adına dava açabilirlerdi. Örneğin İstanbul Eyüp’te Şehzadegan Mescidi Zaviyesi evkafının kurucusu hayattayken-vâkıf şartı aleyhine- vakfa ait olan mutfak ve tuvaleti kendi özel mülküne dâhil edip kullanıyordu. O vefat ettikten sonra aynı davranışı sergileyen damat hakkında mütevelli davacı olmuştu. ${ }^{73}$

Mütevelli, bir kişiyi -örneğin vakfın başka bir şehirdeki alacağını tahsil etmesi içinkendisine vekil tayin edebilirdi. ${ }^{74}$ Mütevelli başka bir yere gideceği için de vakfın işlerini yürütmek üzere yine bir kişiyi vekil tayin edebilirdi. ${ }^{75}$ Mütevellinin ya da vâkıfın tespit edilemediği durumlarda mahkeme bir karara varmayı tercih etmiyordu. Vefat eden bir kişinin vakfa olan borcuna karşılık olarak oğlunun ödeme yapması talebine mahkeme tarafından cevaben "meblă̆-ı mezbûrun vâkıfı ve mütevellîsi ma'lûmları olmayıp ve mütevellîsi tarafindan dahi vekîl olmayıp bir vechile tashîh-i da'vâ edememekle mezbûrûnun müdde'âları meşrû'a olmamă̆ın mezbûr Yorgi'ye suâl dahi teveccüh etmeyip" "76 karşılığ 1 verilmiştir. Burada kadı, eğer vakfın bir alacağ1 varsa bir dava görülebilmesi için vakfın kurucusu ya da mütevellisinin başvuruda bulunması gerektiğini vurgulamıştır.

Hak ehliyeti içerisinde anılan diğer bir kriter borçlu ve alacaklı olabilme şartıdır. Şer'iye sicillerinde bu konuya dair çokça örneğe rastlamak mümkündür. Birkaç örnekle yetinirsek; İstanbul'da Mustafa b. Hasan, "karzdan iki bin akçe ve tarih-i kitaba gelince müeccel bir yıllık çuka-bahasından iki yüz elli akçe ceman iki bin iki yüz elli akce zimmetimde deynimdir" ifadesiyle Hacı Piri Vakfi'na borçlu olduğunu mahkeme huzurunda kabul etmiştir. ${ }^{77}$ İstanbul'da Seyyid Abdi adlı kişi mahkemede Hoca Halil Attar Vakfı "haffaf dükkânı icaresinden iki bin üç yüz kırk akçe zimmetimde vacibu'l-eda deynim vardır" diyerek vakfa olan borcunu kabul etmiştir. ${ }^{78}$ Mütevellinin vakfa borçlu olması ${ }^{79}$ da vakfın mütevelliden ayrı bir tüzel kişiliği olduğuna dair

\footnotetext{
72 Üsküdar Mahkemesi, 5 Numaralı Sicil, No: 141, s.96. Vakıf arsasının istibdali işlemi için vakfı temsilen mütevellinin hazır bulunduğu bir örnek olay için ayrıca bkz; İstanbul Ahkâm Defterleri, No: 4/77/216, M. 1756, s.205.

73 Eyüb Mahkemesi (Havâss-1 Refîa), 90 Numaralı Sicil, No: 153, s.184-185.

74 “Vilayet-i Karaman'da Larende kazasına tabi” Ağras nam karyede vaki Döndü Hatun vakfına mütevelli olan Mustafa b. Halil nam kimesne beni İstanbul'da zimem-i nasda olan mal-ı vakfı da'va ve taleb ve kabza vekil nasb etmişdir", bkz; İstanbul Mahkemesi, 3 Numaralı Sicil, No: 528, s.360-361.

75 "Bir husûs için ben âhar diyâra âzim olmağla tevliyet-i merkümenin hizmet-i lâzımesini görmek için tarafimdan merkūm İbrahim Efendi'yi vekîl ve menâbıma nâib-i menâb nasb ve ta'yîn eyledim”, bkz. Bâb Mahkemesi, 54 Numaralı Sicil, No: 472, s.387.

76 Galata Mahkemesi, 90 Numaralı Sicil, No: 122, s.129.

77 İstanbul Mahkemesi, 3 Numaralı Sicil, No: 57, s.91. Benzer bir örnekler için bkz. a.e., No: 148, s.142-143; No: 195 , s.168.

78 İstanbul Mahkemesi, 3 Numaralı Sicil, No: 82, s.104. Benzer örnekler için bkz. Üsküdar Mahkemesi, 5 Numaralı Sicil, No: 590, s.322-323.

79 "Min ba'd asl-ı mal-ı vakıfdan ve yevm-i vefatına gelince makbuzu olan ribhinden muteveffa-yı mersum [bir önceki mütevelli] zimmetinde bir akce ve bir habbe bakī kalmadı..." bkz; İstanbul Mahkemesi, 3 Numaralı Sicil, No: 111, s.120. Benzer örnekler için bkz. Üsküdar Mahkemesi, 84 Numaralı Sicil, No: 1066, s.548-549; Eyüb Mahkemesi (Havâss-1 Refîa), 90 Numaralı Sicil, No: 466, s.394-395; No: 315, s.292. Bu son örnek davada vakfı temsilen (davacı olarak) -ücretsiz görev yapan-vakıf nazırı hazır bulunmuştur. Bkz. a.e. No: 315, s.292.
} 
diğer bir kanıt olarak gösterilebilir. Bunların yanında, vakıflar alacaklı olduğu gibi borçlu da olabiliyordu. Örneğin İstanbul'da Suriçi’nde dükkânları yangında harap olan Molla Hüsrev Vakfinın bu yapılarının tamir edilmesi için mütevelli kiracılardan borç talep etmiştir. ${ }^{80}$

Bu örnek olaylar, bilhassa sıradan insanların kurdukları, vakıfların gerçek kişiler tarafından yönetilen basit birer mal topluluğu olmadığını; mütevelliden bağımsız bir kişiliği olduğunu göstermektedir. Mahkeme kayıtlarında vakfın hem tüzel kişiliğinin varlığını hem de bu kişiliğin -Avrupa'daki tüzel kişilik hakkının karşısında- zayıflığ1nı gösteren örneklere de rastladık. Bu örnek olaylarda mütevelli, vakfın izni dışında kendi inisiyatifiyle ve mahkemenin izniyle kira işlemi yapmıştır. Örneğin İstanbul İbrahim Paşa Mahallesi’nde çıkan yangında Molla Gürani Vakfı'nın hamamı da yanmış, Hüdaverdi adlı kişi mahkemede; "vakfin musảadesi olmamağın, izn-i mutevelli ve emr-i hakimu'ş-şer' ile ben imaret ve meremmet edip sarf ettiğim doksan altı bin altı yüz altmış dokuz akce ücretinden mahsub olmak üzre mutevelli-i vakf icare-i tavile ile bana icar eylemişdi" ifadesinde bulunmuştur. ${ }^{81}$

\section{Vakıfların Tüzel Kişiliğinin Toplumsal ve İktisadi Boyutu}

Vakıfların tüzel kişiliğinin, hukuki tartışmalar dışında, neden bu kadar önemli olduğu sorusu akla gelebilir. Tüzel kişilik konusu sadece hukuki açıdan önemli değildir; zira bu konu sosyoekonomik gelişmeyle de direkt ilişkilidir. Örneğin Timur Kuran Ortadoğu ve Osmanlıda iktisadi geri kalmışlığın sebeplerinden biri olarak tüzel kişiliğe sahip olmayan vakıfları saymaktadır. Kuran, Ortadoğu'da İslam’ın altın çağından sonra "düşünsel düzeyde gerilemesi”nin temel sebeplerinden biri olarak vakıf kurumunun, değişmez vâkıf şartlarından (vakfiyelerinden) kaynaklanan, "örgütsel sınırlamaları"nı göstermiştir. Yazara göre vakıf, teknolojik gelişmeye ayak uyduramayan, ticari sermaye birikimini ve örgütsel gelişimi engelleyen -esnek olmayan- bir kurumdur. ${ }^{82}$ Kuran’a göre, vakfın özerk olmaması, zamanla fonksiyonunu kaybetmesine yol açabilecektir. Örneğin, tüccarların konaklama ihtiyacı için inşa edilen bir vakıf han ticaret yollarının değişmesi durumunda işlevini hızlı biçimde güncelleyemeyecek ve sonuçta yararsız bir yapıya dönüşecektir. ${ }^{83} \mathrm{Bu}$, aslında vakıflara dair genellemeci ve eksik bir bakıştır. Zira İşeri'nin işaret ettiği üzere, vakfın daimi bir amaca tahsisi toplumsal bir zorunluluk değildir. İslam Hukuku'nda, kadı tarafından amacı kalmamış veya işlevini yerine getirmesi imkânsız hale gelmiş olan vakfın başka bir amaca tahsis edilmesi mümkündür. Örneğin, bir gayrimenkulün mevcut durumunda bir değişiklik yapılması gerektiğinde, vakıf için de faydalı olacaksa vâkıf şartlarına rağ-

80 “Vakfin malı olmayıp, lakin mustécir karz verip ba’dehu mahsul-i vakıfdan haklaşmak..." bkz; İstanbul Mahkemesi, 3 Numaralı Sicil, No: 253, s.203. Yine vakfın tamir ihtiyaçları için mütevelli tarafından vakıf adına borç alındığına dair başka bir sicil kaydı için bkz; Rumeli Sadareti Mahkemesi, 21 Numaralı Sicil, No: 69, s.104. 81 İstanbul Mahkemesi, 3 Numaralı Sicil, No: 77, s.102-103. Benzer bir örnek olay için bkz; "müceddeden binasına canib-i vakıfdan musa’ade olmamağın, vakf-ı mezbur mütevellisi olan Rıdvan b. Abdullah menzil-i mezburu bana icare-i mu'accele-i ma'lume ve yevmi iki akcç ücret-i mueccele ile icar edip ve kendi malım ile ihdas ettiğim bina canib-i vakıfdan icare-i mu'acceleye mahsub olmak üzre izin verip, ben dahi ta'mir ve meremmet etmek", a.e., No: 409, s.293-294.

82 Kuran, Yollar Ayrilırken, s.108, 148.

83 Kuran, “Azgelişmişliğin Kurumsal Kökenleri”, s.58. 
men, kadının kararı ve mütevellinin de izniyle gerekli değişiklikler yapılabilirdi. ${ }^{84}$ Dahası Osmanlı'da vakıf kurucuları, gelecekte yaşanacak değişken şartları göz önüne alarak, başlangıçta esnek bir vakfiye de hazırlayabilirdi. ${ }^{85}$ Deguilhem ise farklı bir bakışla, vakıfların statik ve el değiştirilemez olmadıklarını; vakıf mülklerinin sadece istibdal ve irsad (tahsis) gibi yasal yollarla sık sık el değiştirdiğini hatırlatmıştır. Ayrıca vakıfların piyasa talepleri doğrultusunda ekonominin ayrılmaz bir parçası olduğu görüşündedir. Ona göre, Osmanlı vakıf ekonomisi ve siyaseti, bireylerin, toplumun ve devletin ihtiyaçlarına cevap verebilen esnek ve istikrarlı bir sisteme dayanıyordu. ${ }^{86}$

Osmanlı vakıflarının sahip oldukları iktisadi kaynakları israf ettikleri veya etkinsiz kullandıkları da öne sürülmüştür. Örneğin Kuran’a göre, tüzel kişiliğe ve esnek bir yapıya sahip olmayan vakıf sistemi sebebiyle varlıklı kişilerin sermayeleri ticaret sektöründen, risk ve rekabet içermeyen vakıf sektörüne kaymıştır. Bu da İslam ve Osmanlı topraklarında modern şirketlerin ortaya çıkışını geciktirmiştir. ${ }^{87}$ Çizakça ise Osmanlı'da iltizam yöntemi yoluyla vergi toplamadan sağlanan kârların diğer sektörlere nazaran daha yüksek olduğuna dikkat çekmiştir. Dolayısıyla, aslında Osmanlıda varlıklı kişiler sermayelerinin büyük bir kısmını vakıf alanına değil iltizam sektörüne aktarmışlardır. Bu sebeple Çizakça’ya göre, kaynakların etkinsiz dağılımı, vakıf kurumundan ziyade iltizam sisteminden kaynaklanmıştır. ${ }^{88}$ Orbay’a göre, sultani ve diğer büyük vakıfların iktisadi etkinliğini belirleyen temel unsurlar ise; vakfın kuruluş amacı, mali-idari kararlarını sınırlayan şartları (vakfiyesi), devletin bu karar ve uygulamalara müdahalesi ve vakıf üzerindeki kontrol gücüdür. Diğer taraftan vakıflar, zaten prensip olarak ticari ortaklık/modern şirket olma amacıyla kurulmazlar ve doğal olarak ticari işlerini bir ortaklık gibi yürütemezler. ${ }^{89} \mathrm{Bu}$ özellikleri sebebiyle vakıflar, Kuran'ın görüşünün ${ }^{90}$ aksine, şirketler gibi özerklikleri olsa dahi korporasyonlara/modern şirketlere dönüşecek ya da onlara alternatif olacak kuruluşlar olarak görülemezler.

Gerçekten Osmanlı vakıfları çağdaşları olan Avrupa ve Kuzey Amerika’daki örneklere nazaran güçlü bir tüzel kişiliğe sahip olmasalar da mali durumları ve yönetimleri iyi olduğu sürece asırlarca ayakta kalmışlardır. Dahası Osmanlılar, hukukçuların büyük tartışmaları eşliğinde para vakıflarını kurmuşlardır. Bunlar Osmanlı vakıf kurumunun, esneklik gösterebildiğine dair diğer kanıtlar olarak gösterilebilir. Osmanlı vakıfları, zamanın değişen ve farklılık arz eden sosyoekonomik koşullarına rağmen hizmetlerine devam edebilmişlerdir. Yapısal şartlarından dolayı iktisadi açıdan etkinsiz olan bir kurumun asırlar boyunca hayatını devam ettirmesi de mümkün değildir. Vakıf kurumunun sürekliliğine ve işlevine ket vuran esas kırılma noktası Tazimat

84 İșeri, "Vakıflar", 74, 212; Hâtemî, Medenî Hukuk Tüzel Kişileri, s.650.

85 Murat Çizakça, "Review of The Long Divergence: How Islamic Law Held Back the Middle East by Timur Kuran", Review of Middle East Studies, 45/1 (2011), s.118.

86 Deguilhem, "Wakf", s.88.

87 Kuran, “Azgelişmişliğin Kurumsal Kökenleri”, s.58-59.

88 Çizakça, "Suçlu Şeriat mıydı?”, s.17.

89 Kayhan Orbay, “The Economic Efficiency of Imperial Waqfs in the Ottoman Empire”, XIV International Economic History Congress, Helsinki, erişim 2 Temmuz 2018, https://www.academia.edu/5979515/The_ Economic_Efficiency_of_Imperial_Waqfs_in_the_Ottoman_Empire, s.1-3.

90 Kuran, "Azgelişmişliğin Kurumsal Kökenleri”, s.57-58. 
Dönemi'nde vakıflar aleyhine benimsenen merkeziyetçi ve modernist politikalar olmuştur.

Tabii ki vakıflar toplumsal ve iktisadi açıdan her yönüyle olumlu niteliklere sahip değildir. Osmanlı tebaasından hali vakti yerinde olanların bazıları servetinin annesi, eşi ve kızları da dâhil olmak üzere mirasçıları arasında bölünmesine mani olmak ve servetini erkek çocuk ve torunlarına bırakmak amacıyla da vakıf kurma yoluna gitmişlerdir. Hatta Hüseyin Naci’ye göre, bu yolla vakıf kurma eylemi yüzünden, bazı Avrupalı yazarlar arasında vakfı yeni bir veraset kurumu olarak yorumlayanlar da olmuştur. ${ }^{91}$

Hüseyin Naci'ye göre Osmanlı döneminde vakıfların bu kadar “hüsn-i kabul” görüp sayıca artmasının üç temel sebebi vardı. Bunlardan ilki yukarıda bahsedildiği üzere, vakfın bir veraset aracı olarak kullanılmasıydı. İkincisi bilhassa evlatlık vakıfların, servetin-mülkiyetin müsadereden korunması ve sonraki nesillere aktarılması amacıyla tercih edilmesiydi. Bu sebeple, evlatlık vakıflar esasında "müessese-i diniye değil, daha ziyade bir müessese-i iktisadiye” mahiyetini almıştı. Vakıf kurumunun Osmanlı kültürüne yerleşmesinin üçüncü temel sebebi de vakfın, kurucuyu sonradan gerçekleşecek borcundan dolayı aleyhinde başlayacak adli takipten korumasıydı. Zira vakıf, üzerinde alacak iddiasında bulunulamayacak bir mal idi. Vakıf kurucu borçlu değilken vakfı kursa ancak sonrasında borçlansa, öldükten sonra başka terekesi dahi yoksa buna rağmen alacaklılar vakıf malına dokunamazd $1 .^{92}$

\section{Sonuç Yerine}

Vakıfların tüzel kişiliği tartışmasını günümüz hukuk anlayışındaki kurallara ve normlara göre yapmak bizi anakronizme sürükleyecektir. Buna ek olarak tüzel kişilik kavramının ve konusunun esasında Avrupa Hukuku'na özgü olduğunu da unutmamak gerekir. Dolayısıyla Osmanlı vakıflarının tüzel kişiliğini ve özerkliğini dönemin sosyoekonomik ve hukuki şartlarını dikkate alarak karşılaştırmalı biçimde incelemek gerekir. Dahası, Avrupa ve İslam hukuk rejimleri karşılaştırılırken literatürde genellikle İslam Hukuku, Avrupa Hukuku temel alınarak değerlendirilmektedir. Bu yöntemde, Avrupa Hukuku'na has teorik ve pratik çerçevenin üstün konuma yerleştirildiği bir yaklaşım sorunu ortaya çıkmaktadır. Oysa İslam Hukuku’nu kendi şartları içerisinde değerlendirip, zaman-mekân ayrımını gözden kaçırmadan karşılaştırmayı bu bakış açısıyla yapmak gerekir. Her iki hukuk rejiminin benzerlikleri ve farklılıkları ancak bu yolla daha açık biçimde tespit edilebilir.

$\mathrm{Bu}$ yöntemle kurgulanan çalışmamızın çıkarımlara göre, vakıfların vakfiyelerine göre yönetilmesi, organları/mütevellileri yoluyla kendi gelir-giderlerini idare etmesi, davalı ve davacı olabilmesi, malvarlığına sahip olması, borçlu ve alacaklı olabilmesi, haksız fillerinden sorumlu olabilmesi -kısaca hak ve fiil ehliyetinin olmasi- Osmanlı vakıflarının tüzel kişiliğe sahip olduğuna dair kanıtlardır. Diğer taraftan, darüşşifa tabibi, göz hekimi vb. görevlilerin tayin edilmesi, ücretlerinin artışı, vakıf binalarının

91 Hüseyin Naci, "Vakfa Dair Bir Tedkik", s.99. Bu konuda ayrıca bkz; Çizakça, "Suçlu Şeriat mıydı?”, s.7. 92 Hüseyin Naci, "Vakfa Dair Bir Tedkik”, s.97, 102-103, 106. 
tamiri gibi kararların merkezi idare/padişah tarafından verilmesi, merkezin denetim ve yaptırım (monitoring-sanctioning) gücünün yadsınamayacak düzeyde olduğunu göstermektedir. Bu olgular fiiliyatta vakıfların tüzel kişiliklerini zedeleyen önemli unsurlardır. Dolayısıyla, dönemin hukuk kurallarını ve sosyoekonomik sistemin şartlarını da dikkate aldığımızda Osmanlı vakıflarının İslam Hukuku’na göre aslında tüzel kişiliğe sahip oldukları; ancak, merkezin idari vesayetinin güçlü olması sebebiyle, bu tüzel kişiliğin Avrupadaki muadilleri karşısında uygulamada zayıf kaldığı görülmektedir. Bu durumun bir sebebi de "tüzel kişilik" kavramının ve kurumunun özü itibariyle Avrupa Hukuku’na ait olmasıdır.

Bu çalışmanın literatüre katkı olarak dikkat çekmeyi amaçladığı esas husus, Osmanlı vakıflarının tüzel kişilikleri tartışılırken vakıf türlerinin göz önüne alınması gerektiğidir. Zira farklı vakıf çeşitleri, fiiliyatta ortaya çıkan tüzel kişiliğin boyutunu da etkilemektedir. Örneğin merkezi idarenin ya da doğrudan padişahın kontrolündeki büyük vakıfların de facto tüzel kişilikleri sıradan insanların kurdukları vakıfların ve aile vakıflarının tüzel kişiliklerine nazaran daha zayıftır. Çünkü sultani vakıfların veya devlet adamlarının kurdukları vakıflar asırlarca merkezi görevliler tarafından -doğrudan tüzel kişilik tanınmadan, sanki bir kamu kuruluşu gibi- idare edilmiş ya da sıkı denetim altında tutulmuştur. Bu durum vakıf idarelerinin kendi kararlarını almalarını ve uygulamalarını sınırlamıştır. Oysa küçük çaplı vakıflar ile aile vakıflarında, gerek idari gerekse hukuki işlemlerde mütevelli ya da kurucuların serbestliği/ bağımsızlığı bu büyük vakıflara nispetle yüksektir. Diğer yandan, merkezi idarenin küçük vakıflar ile aile vakıfları üzerinde de güçlü bir idari vesayeti olduğu unutulmamalıdır.

Bunların yanında Evkaf Nezareti'nin kurulmasıyla ortaya çıkan mazbut vakıflar ile mülhak vakıfların tüzel kişilikleri de tartışmaya değerdir. Mülhak vakıflar tüzel kişiliğe sahiptirler; çünkü gerçek kişiler gibi hukuki işlemler/sözleşmeler yapabilir, alacaklı veya borçlu olabilirler, fiillerinden sorumlu olup, borçlarını da kendi gelirlerinden öderler. Mazbut vakıflar ise bu haklara sahip değildir; bu vakıfların her birinin fiillerinden, işlemlerinden ve borçlarından Evkaf Nezareti, sonrasında Vakıflar Genel Müdürlügüu sorumlu olmuştur. Bu yüzden çalışmada, mazbut vakıfların tüzel kişiliği konusunun tartışmalı olduğuna dikkat çekilmiş; organları (mütevellileri) olmayan ve doğrudan bir kamu kuruluşu tarafından yönetilen bu vakıfların fiiliyatta tüzel kişiliğiyle yaptığı idari ve hukuki işlemlerin ortadan kaybolduğuna dikkat çekilmiştir.

Diğer bir tartışma konusu vakıfların kamu tüzel kişisi mi yoksa özel hukuk tüzel kişisi mi olduğudur. Burada da yine vakıf türünü dikkate alan bir yaklaşım sergilenmiş; sultani vakıflar gibi büyük çaplı irsadi vakıfların neredeyse bir kamu kuruluşu gibi idare edilmeleri ve kamu hizmetlerini yerine getirmeleri sebebiyle teorik olarak kamu hukuku tüzel kişisi kabul edilebilecekleri kanaati hâkim olmuştur. Bu bağlamda, küçük çaplı ve sıradan kişilerin kurdukları vakıflar ile özel mülkiyete varan uygulamalarıyla aile vakıfları ise günümüzdeki gibi özel hukuk tüzel kişileri olarak kabul edilebilir. 
Çalışmada son olarak Osmanlı vakıflarının tüzel kişiliği ile iktisadi gelişme konusu birlikte ele alınmıştır. Vakıfların tüzel kişiliğinin varlığı ya da yokluğunun, Osmanlı’nın iktisadi ve sosyal az gelişmişliğinin sorumlusu olamayacağı kanaati hâkim olmuştur. Osmanlı vakıfları, İslam hukuk teorisine göre ve zayıf da olsa pratikte tüzel kişiliğe sahiptir. Vakıf, nispeten esnek bir kurum olarak asırlarca yaşamaya devam etmiştir. Osmanlı ekonomisinde kayda değer bir ağırlığa sahip olan vakıf kurumu, birçok kamu hizmetini yerine getirmiş ve beşeri sermaye birikimini, üretimi, tüketimi, bölüşümü desteklemiş önemli bir kültürel-iktisadi aktördür. Bunun yanında iktisadi gelişme konusu işlenirken, kuruluş ve faaliyet amaçları birbirinden farklı olduğu için, vakıfların Avrupa menşeli ticari ortaklıklarla karşılaştırılması doğru bir yaklaşım olmayacaktır.

Kaynakça

\section{Başbakanlık Osmanlı Arşivi (BOA)}

BOA, İE.SH 1/24, M. 1686; BOA, İE.EV 13/1581, M. 1686; BOA, İE.SH 2/180, M. 1719.

\section{Şer'iye/Kadı Sicilleri}

İstanbul Kadı Sicilleri. Üsküdar Mahkemesi. 5 Numaralı Sicil (H. 930-936/M.15241530). Edit., Coşkun Yılmaz. İstanbul: İSAM Yayınları, 2010.

İstanbul Kadı Sicilleri. Üsküdar Mahkemesi. 84 Numaralı Sicil (H. 999-1000/M. 1590-1591). Edit., Coşkun Yılmaz, İstanbul: İSAM Yayınları, 2010.

İstanbul Kadı Sicilleri. Rumeli Sadareti Mahkemesi. 21 Numaralı Sicil (H. 10021003/M.1594-1595). Edit., Coşkun Yılmaz, İstanbul: İSAM Yayınları, 2011.

İstanbul Kadı Sicilleri. İstanbul Mahkemesi. 3 Numaralı Sicil (H. 1027/M. 1618). Edit., Coşkun Yılmaz, İstanbul: İSAM Yayınları, 2010.

İstanbul Kadı Sicilleri. Galata Mahkemesi. 90 Numaralı Sicil (H. 1073-1074/M. 1663). Edit., Coşkun Yılmaz. İstanbul: İSAM Yayınları, 2012.

İstanbul Kadı Sicilleri. Eyüb Mahkemesi (Havâss-1 Refîa). 90 Numaralı Sicil (H. 10901091/M. 1679-1680). Edit., Coşkun Yılmaz. İstanbul: İSAM Yayınları, 2010.

İstanbul Kadı Sicilleri. Bâb Mahkemesi. 54 Numaralı Sicil (H. 1102/M. 1691). Edit., Coşkun Yılmaz. İstanbul: İSAM Yayınları, 2011.

\section{Diğer Kaynaklar}

Akgündüz, Ahmet. İslâm Hukukunda ve Osmanlı Tatbikatında Vakıf Müessesesi. Ankara: Türk Tarih Kurumu Yayını, 1988.

Alkan, Mustafa. “Türk Tarihi Araştırmaları Açısından Vakıf Kayıtlar Arşivi”. Vakıflar Dergisi. 30 (2007): 1-34.

Barkan, Ömer Lûtfi. "Şehirlerin Teşekkül ve İnkişafı Tarihi Bakımından: Osmanlı İmparatorluğunda İmaret Sitelerinin Kuruluş ve İşleyiş Tarzına Ait Araştırmalar”. İstanbul Üniversitesi İktisat Fakültesi Mecmuası. 23/1-2 (1963): 239-296. 
Cansel, Erol. "Vakıf, Kuruluşu, İşleyişi ve Amacı”. Vakıflar Dergisi. 20 (1988): 321327.

Çizakça, Murat. “Gerçekten de Suçlu Şeriat miydı?”. Erişim 10 Haziran 2018. https://www.academia.edu/4588011/Gercekten_de_Suclu_Seriat_miydi, 1-25.

Çizakça, Murat. "Waqf and Reforming the Higher Education". Paper to be Submited at the Higher Education Forum-Waqf Revival, Malaysia, Kuala Lumpur, 22.02.2018. Erişim 5 Haziran 2018. https://www.academia.edu/35870638/Waqf_ and_Reforming_the_Higher_Education. 1-6.

Çizakça, Murat. "Review of The Long Divergence: How Islamic Law Held Back the Middle East by Timur Kuran". Review of Middle East Studies. 45/1 (2011): 117 119.

Deguilhem, Randi. The Encyclopedia of Islam. 2nd Edition. "Wakf, In the Ottoman Empire to 1914”. XI. Leiden: Brill, 2002, 87-92.

Eren, Fikret. “Osmanlı Dönemi Vakıfları”. V. Vakıf Haftası Kitabı içerisinde. Ankara: Vakıflar Genel Müdürlüğü Yayını, 1988, 195-201.

Eren, Fikret. "Vakıf Mevzuatının Aksayan Yönleri Semineri Paneli”. VII. Vakıf Haftası (5-7 Aralık 1989). Haz., İ. Ateş, S. Bayram, M. Narince, Ankara: Vakıflar Genel Müdürlüğü, 1990, 167-170.

Ertem, Adnan. “Osmanlıdan Günümüze Vakıflar”. Vakıflar Dergisi, 36 (2011): 25-65.

Furat, Ahmet Hamdi. “İslam Hukukunda Vakıf Akdinin Bağlayıcılığı”. İstanbul Üniversitesi İlahiyat Fakültesi Dergisi. 27 (2012): 61-84.

Gözler, Kemal. İdare Hukuku. C. 1. 1. Bask1. Bursa: Ekin Kitabevi, 2003.

Hâtemî, Hüseyin. "Vakıf Kurumuna Hukuk Tarihi Açısından Genel Bir Bakış". İstanbul Üniversitesi Hukuk Fakültesi Mecmuası. 55/4 (1997): 111-128.

Hâtemî, Hüseyin. Medenî Hukuk Tüzel Kişileri: Giriş, Tarihi Gelişim, Eski Vakıflar. C. I. İstanbul: İstanbul Üniversitesi Hukuk Fakültesi Yayınları, 1979.

Hüseyin Naci. "Vakfa Dair Bir Tedkik”. Darülfünun Hukuk Fakültesi Mecmuası. 2/12 (Teşrini Sani 1338/Kasım 1922): 94-114.

İpşirli, Mehmet. “Osmanlı'da Vakıfların Tarihî Gelişmesi”. Sivil Toplum: Düşünce ve Araştırma Dergisi. 4/15 (2006): 61-72.

İstanbul Ahkâm Defterleri, İstanbul Vakıf Tarihi 1 (1742-1764). Proje ve Yayın Yön., Ahmet Kal'a. Haz., Ahmet Tabakoğlu, Ahmet Kal'a, Salih Aynural vd. İstanbul: İBB Kültür İşleri Daire Başkanlığı İstanbul Araştırmaları Merkezi, 1998.

İşeri, Ahmet. "Vakıflar (Medeni Kanun'dan Önceki ve Sonraki Vakıf Nev'ileri ve Hukukî Mahiyetleri)”. Ankara Üniversitesi Hukuk Fakültesi Dergisi. 21/1 (1964): 199-280.

Köprülü, Fuad. "Vakıf Müessesesinin Hukukî Mahiyeti ve Tarihî Tekâmülü”. Vakıflar Dergisi. 2 (1942): 1-35.

Köse, Murtaza. "İslam Hukuku ve Modern Hukuka Göre Tüzel Kişilik”. EKEV Akademi Dergisi. 1/2 (May1s 1998): 221-230.

Kuran, Timur. “Orta Doğu’daki Ekonomik Azgelişmişliğin Kurumsal Kökenleri”. Kayseri Ticaret Odası Dergisi. (Ekim 2010): 50-59. 
Kuran, Timur. "The Provision of Public Goods under Islamic Law: Origins, Impact, and Limitations of the Waqf System”. Law \& Society Review. 35/4 (2001): 841898.

Kuran, Timur. Yollar Ayrlirken, Ortadoğu'nun Geri Kalma Sürecinde İslam Hukukunun Rolü. Çev., Nurettin Elhüseyni. İstanbul: Yapı Kredi Yayınları, 2012.

Makdisi, George. The Rise of Colleges, Institutions of Learning in Islam and the West. Edinburgh: Edinburgh University Press, 1981.

Onar, Sıddık Sami. İdare Hukukunun Umumi Esasları. C. 1. İkinci Baskı. İstanbul: İsmail Akgün Matbaası, 1960.

Orbay, Kayhan. "The Economic Efficiency of Imperial Waqfs in the Ottoman Empire”. XIV International Economic History Congress. Helsinki. Erişim 2 Temmuz 2018. https://www.academia.edu/5979515/The_Economic_Efficiency_ of_Imperial_Waqfs_in_the_Ottoman_Empire. 1-15.

Ortaylı, İlber. Türkiye Diyanet Vakfı İslam Ansiklopedisi. "Kadı (Osmanlı Devleti’nde Kad1)" maddesi. 24. İstanbul, 2001, 69-73.

Özcan, Tahsin. “Osmanlı Vakıf Hukuku Çalışmaları”. Türkiye Araştırmaları Literatür Dergisi. 3/5 (2005): 513-552.

Özsunay, Ergun. Medenî Hukukumuzda Tüzel Kişiler, Tüzel Kişilerin Genel TeorisiDernekler-Vakıflar. 3. Baskı. İstanbul: İ.Ü. Hukuk Fakültesi Yayınları. 1974.

Öztürk, Nazif. “XIX. Yüzyılda Osmanlı İmparatorluğu’nda Sanayileşme ve 1827'de Kurulan Vakıf İplik Fabrikası”. Vakıflar Dergisi. 21 (1990): 23-80.

Pantık, Ramazan. "Osmanlı'da İcâreteyn Uygulaması Hakkında Yeni Değerlendirmeler”. Vakıflar Dergisi. 48 (2017): 75-104.

Reuter, Ernst. "Beledi Vakıfların Modern Şehir İdaresindeki Ehemmiyetleri”. Çev., Coşkun Üçok. İ.Ü. İktisat Fakültesi Mecmuası. 3/3-4 (1942): 329-343.

Sarı, Nil. Türkiye Diyanet Vakfı İslam Ansiklopedisi. “Tıp (Osmanlı Dönemi)” maddesi. 41. İstanbul, 2012, 101-111.

Taşkın, Âlim. “Tüzel Kişilerin Kişilik Haklarının Korunması”. Ankara Üniversitesi Hukuk Fakültesi Dergisi. 42/1 (1992): 203-243.

TBMM Zabit Ceridesi. C. 4. 33. İnikad. 03.06.1935. Erişim 30 Haziran 2018. https:// www.tbmm.gov.tr/tutanaklar/tutanak/tbmm/d05/c004/tbmm05004033.pdf.

Vakıflar Kanunu (2762 Sayılı). Erişim 1 Temmuz 2018. http://www.resmigazete.gov. tr/arsiv/3027.pdf.

Yılmaz, Yasin. "Kanunî Vakfiyesi ve Süleymaniye Külliyesi (Eğitim, Kültür ve Sosyal Yönü-Başlangıçtan 1600'e Kadar)”. Doktora Tezi. Ankara Üniversitesi, 2002.

Zahraa, Mahdi. "Legal Personality in Islamic Law”. Arab Law Quarterly. 10/3 (1995): 193-206. 
İNSAN\&İNSAN, Y11/Year 6, Sayı/Issue 19, Kış/Winter 2019, 9-31

DOI: https://doi.org/10.29224/insanveinsan.446622

\section{Did Ottoman Waqfs have a Juristic Personality?}

YAKUP AKKUŞ

Abstract: The concept and institution of juristic personality is inherently owned by Western European Law. The juristic personality of the Islamic and Ottoman waqfs is not adequately examined in the literature. In this study, according to the Islamic Law, it is accepted that Ottoman waqfs have a juristic personality in general, taking into account the criteria such as managing waqfs according to their waqfiyyas, managing them with their own revenueexpenses, being a defendant-plaintiff and a debtor-creditor, and possessing assets. However, the juristic personality of the Ottoman waqfs is, in fact, weaker than the similar ones in Europe, due to strict control or direct intervention of the state in the waqf administration. Besides these, while the juristic personality of the waqfs are discussed, it is necessary to consider the types of the waqfs. For instance, de facto juristic personality of the sultanic waqfs and large waqfs are weaker than the juristic personality of small waqfs and family waqfs. In addition, "mülhak waqfs" have a juristic personality, but "mazbut waqfs" not. Because, none of "mazbut waqfs" have own organ, and are administrated by Ministry of Awqaf. The study also addresses the theoretical relationship between the juristic personality of waqfs and economic development.

Keywords: Law of waqf, Juristic personality, Autonomy, Ottoman waqfs, European waqfs. 